\title{
onmbalina
}

(8)

\section{Noções basilares sobre a morfologia e o léxico}
Autor(es):
Rodrigues, Alexandra Soares
Publicado por: Imprensa da Universidade de Coimbra
URL persistente:
URI:http://hdl.handle.net/10316.2/38913
DOI:
DOl:http://dx.doi.org/10.14195/978-989-26-0864-8_1

Accessed : $\quad$ 26-Apr-2023 11:25:18

A navegação consulta e descarregamento dos títulos inseridos nas Bibliotecas Digitais UC Digitalis, UC Pombalina e UC Impactum, pressupõem a aceitação plena e sem reservas dos Termos e Condições de Uso destas Bibliotecas Digitais, disponíveis em https://digitalis.uc.pt/pt-pt/termos.

Conforme exposto nos referidos Termos e Condições de Uso, o descarregamento de títulos de acesso restrito requer uma licença válida de autorização devendo o utilizador aceder ao(s) documento(s) a partir de um endereço de IP da instituição detentora da supramencionada licença.

Ao utilizador é apenas permitido o descarregamento para uso pessoal, pelo que o emprego do(s) título(s) descarregado(s) para outro fim, designadamente comercial, carece de autorização do respetivo autor ou editor da obra.

Na medida em que todas as obras da UC Digitalis se encontram protegidas pelo Código do Direito de Autor e Direitos Conexos e demais legislação aplicável, toda a cópia, parcial ou total, deste documento, nos casos em que é legalmente admitida, deverá conter ou fazer-se acompanhar por este aviso. 


\section{GRAMÁTICA \\ DERIVACIONAL \\ DO PORTUGUÊS}

GRAÇA RIO-TORTO

ALEXANDRA SOARES RODRIGUES

ISABEL PEREIRA

RUI PEREIRA

SÍLVIA RIBEIRO

2. ${ }^{a}$ EDIÇÃO

IMPRENSA DA UNIVERSIDADE DE COIMBRA COIMBRA UNIVERSITY PRESS 


\section{CAPÍTULO 1. NOÇÕ ES BASILARES SOBRE A MORFOLOGIA E O LÉXICO}

Alexandra Soares Rodrigues

O estudo da gramática derivacional duma língua é um estudo sobre "formação de palavras", nas duas aceções que esta comporta. Uma diz respeito a uma competência da gramática mental dos falantes. Outra refere um domínio de descrição linguística que pretende descrever e explicar a primeira.

$\mathrm{Na}$ primeira aceção, está em causa um domínio mental em que concorrem, através de interfaces, as estruturas da linguagem que intervêm na produção de lexemas pelos falantes. Estas estruturas são a morfologia, a semântica, a fonologia e, indiretamente, a sintaxe (Aronoff 2000; Booij 2000a; Corbin 1987; Spencer 2000). A formação de palavras, como domínio convergente dessas áreas em interface (Rodrigues 2008, 2012, 2015; Rodrigues Rio-Torto 2013), mostra que a linguagem é constituída por estruturas que contactam entre si interativamente (Jackendoff 2002). Todas essas estruturas possuem componentes que, produtivamente, são acionados para a formação dos lexemas, sejam estes novas unidades da língua ou unidades já existentes, mas cuja formatividade pode ser ativada na mente do falante no momento da produção do discurso (Bauer 2006).

$\mathrm{Na}$ segunda aceção integram-se as descrições e as explicações que a linguística, enquanto ciência de estudo da linguagem, aventa para os fenómenos de geração lexical. 
Os elementos de ordem histórica e etimológica não intervêm na formação de palavras enquanto componente da gramática mental. Os falantes não têm acesso a estados pretéritos da língua, nem necessitam de um conhecimento explícito acerca destes para produzirem lexemas, exceto na criação de lexemas com componentes eruditos ${ }^{1}$. Já no que diz respeito à área da linguística que explica a formação de palavras, os dados históricos e etimológicos são instrumentos que auxiliam, a par de outros, a identificação de segmentos morfológicos ou a compreensão da maior ou menor produtividade dos processos. No entanto, esses dados históricos não se sobrepõem aos componentes de caráter sincrónico que ativamente participam na gramática mental do falante. Assim, a formação de palavras como área do conhecimento descreve as estruturas mentalmente congregadas para a geração de lexemas em cada sincronia, recorrendo a informações etimológicas e históricas como auxílio e não como objeto em si mesmo.

A formação de palavras recobre diferentes processos, que agem paradigmaticamente, que permitem formar um lexema com base noutro lexema, sejam a afixação, a conversão, a composição, a amálgama ou cruzamento, a truncação. A derivação, em sentido lato, é encarada como equivalente de formação de palavras. É nessa aceção que é usado o adjetivo derivacional no título deste livro.

Neste capítulo descrevem-se conceitos básicos referentes às unidades envolvidas na formação de palavras em português, às relações genolexicais estabelecidas entre aquelas, aos processos

1 Veja-se, a este propósito, o modo como, segundo Bluteau (1712-1728), a denominação pirilampo foi proposta e criada em português: «Nas conferencias Academicas, que se fizeram no anno de 1696 na livraria do Conde da Ericeira, foy proposto, se ao inseto luzente vulgarmente chamado cagalume se daria em papeis, ou discursos serios, outro nome mais decoroso, como v.g. Pirilampo à imitação de Plinio Histor. que chama a este inseto Lampyris, nome composto de Lampas que em grego val o mesmo que Tocha, e Pyr que quer dizer Fogo.». 
de formação de palavras e às dimensões presentes na produção e na interpretação dos produtos lexicais ${ }^{2}$.

\subsection{Formação de palavras: conceitos básicos}

\subsubsection{Morfologia}

Por morfologia pode entender-se a organização mental da linguagem que estrutura a constituição interna da(s) palavra(s) e a formação desta(s). Em simultâneo, a morfologia é a área da linguística que estuda a organização mental referente à constituição interna das palavras em unidades mais pequenas - os morfemas (Matthews 1974:1-23), aqui encarados como unidades mínimas com função gramatical (Aronoff 1994: 5-29; Plag 2003:10) ${ }^{3}$.

Por constituição interna das palavras entende-se a sua estruturação em morfemas cuja combinação serve para: (i) mudar a forma da mesma palavra de acordo com alterações a nível do significado e da função gramaticais, assim acontecendo quando há variação flexional de uma mesma palavra, sem alterar a identidade da mesma (menino $(S)$ ); (ii) construir palavras. Assim acontece quando derivamos avaliação de avaliar. Neste caso ocorre mudança não só na forma e no significado gramatical, mas também no significado lexical. Esta alteração leva a que avaliar e avaliação não sejam duas formas da mesma palavra, mas duas palavras distintas.

A morfologia flexional trata da constituição interna da mesma palavra, estudando as suas variações formais (gato/gatos; adorou/

\footnotetext{
2 Remete-se o leitor que queira praticar e aferir os seus conhecimentos sobre morfologia e formação de palavras do português para Rodrigues 2012b.

${ }^{3}$ A função gramatical é entendida não no sentido restrito de 'flexional', mas no sentido lato de 'relativo à gramática (mental) da língua'.
} 
adoraram). A morfologia derivacional trata da constituição interna de palavras diferentes, estudando as variações formais e semânticas que permitem construir palavras a partir de outras, como avaliação a partir de avaliar ou como contentamento a partir de contentar e este verbo a partir do adjetivo contente (Štekauer 2015).

A morfologia tem como tarefas analisar os constituintes morfológicos das palavras e o modo como estes se organizam entre si. Para tal é necessário identificar os constituintes, analisar as suas propriedades e compreender a organização que pode existir entre os constituintes para a estruturação de uma palavra ou para a variação da mesma palavra.

A categoria lexical das palavras, ou seja, a pertença às classes nome, verbo, adjetivo, advérbio, etc. diz respeito a informações sobre o modo como a palavra é usada na sintaxe. Por exemplo, lança $(\mathrm{N})$ e lança $(\mathrm{V})$ pertencem a duas categorias lexicais diferentes, como é observável nos títulos «lança $a_{\mathrm{N}}$ atinge adepto»; «banda lança $_{\mathrm{V}}$ novo disco".

\subsubsection{Palavra, lexema, forma de palavra}

Conceitos fundamentais no âmbito da análise morfológica são os de palavra (Carstairs-McCarthy 2000), lexema e forma de palavra. Este último refere-se aos diferentes formatos que o mesmo lexema pode comportar quando ocorre em cotexto.

Um lexema (neste livro transcrito em VERSALETES quando estritamente necessário) é uma unidade lexical abstrata, desprovida de variações cotextuais, como sejam as variações de género/número, tratando-se de nomes e de adjetivos, e de modo-tempo-aspeto e de número-pessoa, tratando-se de verbos (Plag 2003: 9; Haspelmath 2002: 13). Um lexema como AVALIAR encontra-se inscrito no nosso léxico mental, com informações relativas ao seu significado, à sua 
atualização sintática, à sua constituição fonológica (Jackendoff 2002: 131). As variações que podemos fazer desse lexema, através da adjunção de morfemas de modo-tempo-aspeto (avalia+va, avalia+sse, avalia+ria) e de número-pessoa (avalia + s, avalia+mos, avalia + is, avalia+m) não alteram o lexema e, por isso, são designadas por formas de palavra (Haspelmath 2002: 13). Estas são grafadas em itálico. O conjunto das variações da forma do mesmo lexema é designado por paradigma do lexema (Haspelmath 2002: 14).

Um lexema não equivale a uma forma particular, mas a um conjunto de formas, em abstrato, ou melhor, a um padrão mental que regula essas formas, que o falante usa para fazer variar cotextualmente uma unidade lexical. Como tal, para referir avaliação como a unidade localizada no nosso léxico mental em abstrato, usamos AVALIAÇÃO. Esta forma - AVALIAÇÃo - abstrai as variações formais que o lexema possa ter (avaliação/ avaliações).

Já na sua correlação com avaliar, avaliação não representa uma alteração da forma de avaliar, mas uma outra palavra, ou seja, um outro lexema.

Dado o grande número de formas que alguns lexemas podem assumir, usa-se uma forma citacional convencionada para referir um dado lexema. O infinitivo impessoal é, para o português, como para as línguas românicas, a forma citacional (Haspelmath 2002: 14) do verbo. Em latim, por exemplo, a forma citacional é a $1 .^{a}$ pessoa do singular do presente do indicativo (audio do verbo audire). Num dicionário de inglês, procuramos o infinitivo sem to (listen), ou seja, o bare infinitive. No caso dos nomes, a forma citacional é a do singular. Se o nome tiver variação de género, a forma usada para o masculino é a forma citacional.

A forma citacional é um instrumento útil para fazer referência aos lexemas. Contudo, não tem necessariamente importância a nível do léxico mental, pois a forma citacional pode não corresponder à forma que um lexema assume para fazer gerar a partir de si mes- 
mo outros lexemas, ou para fazer variar a sua forma no mesmo paradigma. Em português, a forma do verbo que serve de base de derivação a um substantivo não corresponde à forma citacional: citação advém da forma cita (tema verbal) + ção e não da forma do infinitivo (*citarção). De igual modo, o pretérito imperfeito do indicativo citava obtém-se da junção de -va ao tema cita-, e não ao infinitivo (*citarva) ${ }^{4}$. Já na forma de $1 .^{a}$ pessoa do presente do indicativo, é ao radical, e não ao tema, que se junta o morfema de NP: cit+o (cito) e não cita+o.

Isto significa que, além das múltiplas formas gramaticais dum lexema, a língua dispõe ainda de diferentes formas de cada lexema que servem de base para a geração de outras formas e/ou de outros lexemas. Como estas diversas formas não têm sempre a mesma configuração, compreende-se, assim, que um lexema funcione como um padrão de formas de palavra e não como uma forma apenas.

O latim ilustra de forma exemplar que diferentes formas lexicais estão disponíveis para a obtenção de formas gramaticais de um lexema. Um verbo como caedo disponibiliza um tema para formar o presente (caedo ...) e o pretérito imperfeito do indicativo (caedēbam...) e outro tema para formar o pretérito perfeito do indicativo (cecidi). O mesmo ocorre na formação de palavras do português. Os verbos de tema em - $e$ disponibilizam o tema do presente para formar nomes em -dor (batedor) e o tema do particípio para formar nomes em -ment(o) (batimento), como se observa através da diferença da configuração da vogal temática $(-e /-i)$.

Existem lexemas que não apresentam variação formal. A sua forma mantém-se, mesmo que haja variação no significado da frase em que o lexema está inserido e, logo, na funcionalidade gramatical

${ }^{4}$ Como veremos no cap. 1: 1.1.3.3, 1.6.3, esta precaução em relação à forma citacional revela-se importante para compreendermos os chamados, na gramática tradicional, derivados 'regressivos', ou seja, os derivados conversos. 
(comprei um lápis, comprei dois lápis). Essa situação pode também ocorrer com lexemas sem variação na funcionalidade gramatical. No caso dos advérbios, a invariância formal acompanha a invariância funcional. Os advérbios não apresentam mudança funcional quanto a género, número, tempo, modo, aspeto, etc.

São, pois, palavras variáveis aquelas que mudam a sua forma, para se adequarem a funções gramaticais como género, número, pessoa, tempo, modo, aspeto, caso; são palavras invariáveis aquelas que apresentam sempre a mesma forma.

Sendo difícil a definição conceptual de palavra, recorremos a dois critérios empíricos que permitem a sua identificação (Aronoff \& Fudeman 2005: 37-38): a ordem fixa dos elementos e a inseparabilidade destes.

\section{- Ordem fixa de elementos}

Uma das caraterísticas da palavra é a sua autonomia prosódica. Geralmente, as palavras são unidades que têm acento próprio. Contudo, há palavras que são unidades gramaticais (i. e., têm autonomia do ponto de vista gramatical) e não têm acento próprio. É o caso dos clíticos (Spencer 1991:350-392). Estas unidades têm de ocorrer na frase juntamente com uma palavra que possua um acento próprio e, em conjunto com esta, formam um vocábulo fonológico. É exemplo disso o clítico te, em deu-te o livro; não te deu o livro.

O clítico te funciona em conjunto com deu como um vocábulo fonológico. Podemos dizer que te é um satélite prosódico de deu. A possibilidade de o clítico mudar de posição em relação à palavra de que é satélite fonológico mostra que este, embora não seja autónomo fonologicamente, é autónomo em termos gramaticais.

Comparemos agora o comportamento do clítico com o comportamento de afixos.

Ao contrário do que acontece com os clíticos, os afixos não podem mudar de posição em relação à palavra a que se juntam (cf. 
encabeçou < en+cabeç-; agradecimento < agradeci+ment(o)). Assim se explica a agramaticalidade de *abeçoen e *mentoagradeci.

Podemos, pois, estabelecer como critério de identificação de uma palavra o caráter fixo em que ocorre a ordem dos seus constituintes. Esta é uma caraterística que diferencia as unidades da morfologia das unidades da sintaxe. Mesmo em línguas, como o português, em que a ordem dos constituintes na frase tende a ser padronizada, ela não é, no entanto, absolutamente fixa: em o João comeu o bolo, o bolo comeu-o o João, ou comeu o bolo o João, as frases mantêm-se interpretáveis e gramaticais. $\mathrm{O}$ mesmo não acontece entre os constituintes morfológicos das palavras: desglobalização (des+glob+al+iz+a+ção) não pode ocorrer como *çãoaizalglobdes ou como *çãoglobalizades.

\section{- Inseparabilidade e integridade}

Outra caraterística da palavra é a sua inseparabilidade e a sua integridade.

Um clítico pode ocorrer em posições diversas em relação à palavra da qual é satélite. Um enunciado como embora me não dês o livro, vou contar-te a história, mostra que a dependência prosódica de me não se estabelece obrigatoriamente em relação ao verbo, mas a qualquer palavra a que se possa anexar fonologicamente.

O mesmo não ocorre com os constituintes que formam a palavra.

(1) A desglobalização não passa de um sonbo.

(2) *A des não passa glob iza de um sonho ção.

A inseparabilidade e a integridade constituem critérios eficazes para provar que uma palavra composta é, de facto, uma unidade e não uma frase. Por exemplo, o composto girassol não pode ocorrer como o *giralindossol, mas sim como o girassol lindo ou o lindo girassol. O limpa-para-brisas não pode ocorrer como $o$ *limpa novo para-brisas, mas sim como o limpa-para-brisas novo (Plag 2003: 6-7). 


\subsubsection{O que é o morfema?}

Entende-se por morfema a unidade mínima com função dentro da gramática da língua, ou seja, com função gramatical. Esta definição permite contornar as desvantagens que surgem se considerarmos o morfema como uma ligação entre uma forma e um significado (cf. Aronoff \& Fudeman 2005: 2) ${ }^{5}$.

Em caso de circunfixação, por exemplo, um significado não está relacionado com um morfema coincidente com uma série contínua de segmentos fonológicos, pelo facto de aquele ser descontínuo: em apodrecer 'tornar-se podre', o significado de 'tornar-se' está a cargo de uma unidade descontínua ( $a-\ldots-e c-)$ e, como tal, não se pode relacionar este significado apenas com $a$ - ou apenas com -ec- (cf. cap. 4: 4.3.3.3).

Outras vezes, o contributo do morfema não é o de acrescentar um significado conceptual, mas o de indicar comportamentos formais que uma dada palavra tem de seguir (compare-se o comportamento flexional dos verbos falar e falir, por exemplo). Assim acontece com os constituintes temáticos, como morfemas vazios que são (Aronoff 1994: 44-45; Mateus \& Andrade 2000: 68).

Há ainda situações em que um morfema apresenta variações ao nível do significante, ou seja, nos segmentos fonológicos que

\footnotetext{
$5 \mathrm{Na}$ tradição estruturalista, o morfema é definido como a unidade formal que contém um significado. Esta definição levou à formulação do conceito de 'morfema zero' (Marchand 1960; Kastovsky 1968), com a qual se pretende indicar o 'contentor' de um significado para o qual não existe um morfema que o represente, como o caso do singular em português ou do plural de lápis. O morfema zero acarreta, no entanto, problemas não só teóricos, mas também empíricos (Bauer 1988). Em português, seria necessário conceber um número demasiado elevado de morfemas zero (v.g. para os nomes, cujo singular é representado por uma ausência de morfema; para a $3 .^{a}$ pessoa do singular dos verbos que, à exceção do pretérito perfeito do indicativo, não apresenta morfema). Como nem sempre a funcionalidade das estruturas se faz acompanhar por uma forma que as represente, em vez de se considerar a existência de um morfema zero para cada um dos significados, é mais adequado considerar que a morfologia pode não se socorrer do morfema para operar nas palavras.
} 
o compõem. Esta variação designa-se por alomorfia (Matthews 1974:107; Dressler 2015) e a realização concreta de cada morfema por alomorfe (Plag 2003: 27). Encontra-se neste caso o alomorfe -bil que o sufixo -vel toma em contexto derivacional.

Outros casos há em que parece haver um significado sem forma que o expresse. Por exemplo, a expressão do singular dos nomes em português faz-se pela ausência de morfema, ao contrário do plural que, geralmente, é expresso pelo morfema $-s$. Esta ausência de forma para um significado também ocorre no âmbito da morfologia derivacional, como se observa nas secções seguintes.

Por último, existe alteração a nível do significado e, em simultâneo, a nível da categoria lexical e das subcategorias e categorias sustentadas pela categoria lexical, sem que se observe diretamente alteração formal. É este o caso da formação de nomes e de verbos conversos (abraçar > abraço (cf. cap. 2: 2.4.3); âncora > ancorar (cf. cap. 4: 4.1.2)).

\subsubsection{Constituintes puramente morfológicos ou expletivos}

Tradicionalmente, considera-se o morfema como a unidade mínima com significação (Hockett 1958: 93; 126). No entanto, existem morfemas aos quais dificilmente se consegue atribuir uma significação, se pensarmos nesta em termos conceptuais (Aronoff 1994: 5-29). Os constituintes temáticos dos verbos e dos nomes encontram-se nesta situação.

Observemos a forma de palavra avaliávamos, que segmentamos nos seguintes morfemas:

\section{(3) Avaliávamos}

$\begin{array}{llll}\text { Avali } & a & \text { va } & \text { mos } \\ \text { Radical } & \text { VT } & \text { MMTA } & \text { MNP }\end{array}$


Ao radical avali- conseguimos atribuir o significado lexical de 'julgar, apreciar'; a -va a carga semântica de pretérito imperfeito do indicativo; a -mos a carga de $1 .{ }^{a}$ pessoa do plural. Contudo, a - $a$ (VT) não conseguimos atribuir nenhum significado. Significa isto que não estamos perante um morfema? É possível considerar - $a$ (VT) como morfema, apesar de não lhe estar associado um significado?

Como já foi referido a propósito do estatuto dos constituintes temáticos, um morfema não tem que ter um significado de caráter conceptual. O papel do morfema pode ser funcional, ao evidenciar o comportamento morfológico do lexema em que se insere ao nível flexional ou derivacional (vejam-se os exemplos de falir e falar ou ainda de remir e remar). Por isso se considera que um morfema é uma unidade mínima com função gramatical.

Neste conjunto se inscrevem os interfixos (1.6.1.4 deste cap.), ou seja, os morfemas que se introduzem entre uma base e um sufixo derivacional (cãozinho) ou entre uma base e outra base, como nos compostos (fumívoro) (Haspelmath 2002:86). É uma função de estruturação morfológica a que os interfixos desempenham: mantêm a base interpretável (cãozinho vs. *cãoinho) e evitam a formação de hiatos que dificultam essa interpretação (chaleira vs. *chaeira).

A função destes morfemas que designámos por 'puramente morfológicos', expletivos ou morfemas 'vazios' consiste, não na atribuição de uma carga semântica ao lexema em que se integram, mas na estruturação morfológica da própria identidade do lexema, ou na estruturação do paradigma a que aquele pertence. O morfema possui, assim, uma carga gramatical ou funcional e não apenas ou necessariamente semântica.

\subsubsection{Alomorfia}

Muitas vezes um morfema surge realizado sob formatos fonológicos diferentes. Chama-se a isto alomorfia (Matthews 1974: 107; 
Luschützky 2000). O exemplo do morfema $-s$ de plural mostra que vários morfes podem realizar o morfema. Outros exemplos são visíveis na diferença entre a forma do sufixo -vel quando ocorrente em adjetivos e quando ocorrente dentro de nomes derivados desses adjetivos. Veja-se o adjetivo contornável. Se formarmos um nome de qualidade tomando esse adjetivo como base, o nome será contornabilidade e não *contornavelidade. Vemos que a forma do sufixo -vel ocorre no produto nominal como - bil, como em amabilidade, rentabilidade, etc. Não se explica esta alternância pela possibilidade de se tratar de palavras herdadas do latim, visto que contornabilidade, que não dispõe de correlato latino, ostenta o mesmo formato.

A alomorfia mostra que não é possível encarar o morfema como a ligação entre uma forma e um significado. Na verdade, o mesmo significado pode ser veiculado por formas fonológicas diferentes, que se encontram correlacionadas no léxico mental. A alomorfia não anula, pois, a unidade do morfema. $\mathrm{O}$ falante tem capacidade para distinguir, implicitamente, os cotextos em que ocorre cada forma.

\subsubsection{Ausência de morfema: a formação por conversão}

A morfologia derivacional pode operar com alterações categoriais no léxico sem haver vestígio formal direto dessa alteração ou sem que haja um morfema responsável por essa mudança. É este o caso do processo de conversão que, na gramática tradicional, se designava por 'derivação imediata', quando se forma um verbo com base num nome, ou por 'derivação regressiva', quando se gera um nome com base num verbo (Nunes [1919] 1989: 358-361).

Ao processo de construção destes lexemas são dedicadas a secção 1.6.3 e as secções 2.4 .3 e 4.1.2 dos capítulos 2 e 4. Neste momento, apenas pretendemos mostrar que é possível ocorrer derivação sem que haja um morfema responsável por esse processo. 
Observemos os seguintes exemplos:

(4) relva > relvar

(5) rogar $>$ rogo

Os membros de cada um destes pares têm uma relação derivacional. O elemento da esquerda é derivante e o elemento da direita é o derivado. No entanto, se compararmos a constituição morfológica de verbos entre si e dos nomes entre si (cf. Quadro 1), verificamos que não existe nenhum morfema derivacional que seja responsável pelas derivações.

\begin{tabular}{|l|l|l|l|l|}
\hline \multicolumn{2}{|c|}{ Nome } & \multicolumn{3}{c|}{ Verbo } \\
\hline relv & a & relv & a & $(r)$ \\
\hline radical & IT & radical & VT & MMTA \\
\hline rog & o & rog & a & $(r)$ \\
\hline radical & IT & radical & VT & MMTA \\
\hline
\end{tabular}

Quadro I. 1. Estrutura morfológica dos verbos relvar e rogar e dos nomes relva e rogo

A estrutura morfológica não oferece nenhum dado que mostre qual dos verbos e qual dos nomes é derivado. Radical e VT são constituintes presentes quer em verbos derivados (açucarar, relvar), quer em verbos não derivados (amar, rogar) ${ }^{6}$. Da mesma maneira, radical e índice temático são constituintes presentes quer em nomes não derivados (casa, relva), quer em nomes derivados (rogo, voo).

Por conseguinte, nestes casos não existe nenhum morfema responsável pela conversão, ou seja, pela construção de um derivado

${ }^{6}$ Excluímos o morfema modo-temporal-aspectual de infinitivo por este ser exterior à derivação, uma vez que se trata de um morfema de flexão. Recorde-se que o infinitivo é, casualmente, a forma citacional, sem que haja neste facto importância a nível da formação de palavras. 
a partir de uma base sem recurso à afixação ou à adição de bases (Anderson 1992: 21-22; Rodrigues 2001).

\subsubsection{Morfema vs. palavra}

As considerações antes expendidas servem dois propósitos diferentes, embora interligados. Por um lado, mostram a distinção entre palavra e morfema, ou seja, mostram o que é e não é uma palavra, por se tratar de um elemento mais pequeno do que aquela, e funcionando portanto como uma unidade hierarquicamente interna à palavra e/ou a ela anterior. Neste caso estamos no domínio da morfologia. Por outro lado, evidenciam o que é uma palavra e o que não é uma palavra por se tratar de um elemento mais extenso (ou seja, por ser hierarquicamente superior ou externo à palavra). Neste caso estamos no domínio da sintaxe.

Os critérios de identificação de palavras ajudam a perceber que a morfologia é um domínio autónomo em relação à sintaxe (Matthews 1974: 206-222; Jackendoff 2002: 128-129). O tipo de organização interna da palavra não segue os mesmos modos de funcionamento que o tipo de organização interna da frase. A morfologia dedica-se à análise da estrutura interna das palavras, pelo que não cabe à morfologia estudar a organização das palavras na frase, assim como não cabe à sintaxe estudar a organização interna das palavras.

Coloca-se a este propósito a distinção entre palavra e morfema. Um morfema é uma unidade mínima com função na gramática da língua. O morfema pode coincidir com uma palavra ou não. As preposições $(d e, a)$ e os afixos (-s, -va, -ção, re-) são morfemas. A questão que se coloca é: estamos também em todos os casos perante palavras? Um morfema equivale sempre a uma palavra?

A aplicação do critério de mudança de posição permite concluir que as preposições $a$ e de são morfemas e palavras. 
(6) Assisti a uma reunião importante.

(7) A reunião a que assisti era importante.

(8) O João gosta de chocolate, mas não gosta de amêndoas.

(9) De que é que o João gosta?

A mesma possibilidade de mudança de posição não se verifica nos morfemas presos $-s,-v a$, re-, -ção. Vejam-se os exemplos: gatos vs. *sgato; estudava vs. *vaestuda; reanimar vs. *animarre; recordação vs. *çãorecorda.

Os morfemas podem, pois, ser presos ou autónomos (Herculano de Carvalho 1984: 473-477). Se autónomos, correspondem a uma palavra; se presos, não.

\subsubsection{Derivação vs. Flexão}

A constituição interna das palavras pode ser alterada em função de dois propósitos fundamentais (Štekauer 2015):

1) manter o mesmo lexema, alterando o seu formato, ou seja a forma de palavra, com a intenção de adequá-lo ao cotexto sintático, obtendo-se assim diferentes palavras gramaticais. Esta situação é tradicionalmente designada por flexão.

2) formar outro lexema a partir do primeiro, obtendo-se dois lexemas distintos. Trata-se aqui de derivação, no sentido mais amplo desta palavra.

Em termos de flexão, o lexema cuja forma citacional é amarelo pode ocorrer nas formas amarelos, amarela, amarelas. O lexema cuja forma citacional é desconfiar pode ocorrer, por exemplo, nas formas desconfio, desconfiaram, desconfiarás, desconfiou, etc. Esta alteração formal do lexema é exigida pela sintaxe. Como tal, a flexão 
resulta da necessidade de conciliar a forma do lexema com a frase. Por exemplo, numa frase como As folhas estão amarelas o formato do lexema AMARELO ocorre como amarelas para que possa haver concordância em género e número com folhas. A flexão transporta morfologicamente informação morfossintática: caso, modo, aspeto, tempo, pessoa, número (Matthews: 42-60).

A flexão não altera a categoria lexical da palavra, nem a sua semântica lexical. Assim, avaliaremos continua a ser um verbo que significa 'determinar a valia de; apreciar; julgar'. A forma avaliaremos pode surgir numa frase na mesma posição em que surge avalias (10-11):

(10) Avalias o aluno.

(11) Avaliaremos o aluno.

A derivação altera, em geral, a categoria lexical da palavra, bem como a sua semântica (Matthews 1974: 61-81). Como tal, uma palavra derivada de outra não pode ocorrer no mesmo cotexto ou mantendo a mesma significação da primeira (12-13):

(12) Avalias o aluno.

(13 *Avaliação o aluno.

Em 14. a forma do lexema AVALIAÇÃo exige um cotexto frásico em que ocorra uma preposição entre avaliação e aluno, dado que o nome só se relaciona com os seus complementos nominais através de preposição. Por outro lado, deve ocorrer um determinante à esquerda de avaliação (14):

(14) A avaliação do aluno.

Acresce que dificilmente podemos considerar que o significado de avaliação seja o mesmo de avaliar. Ainda que os semantismos 
de ambos estejam relacionados, a relação semântica entre avaliação e avaliar não é do mesmo tipo daquela que relaciona o significado de avalio e de avalias. Neste último caso, prevalece o mesmo significado referencial.

Outra caraterística que distingue a flexão da derivação tem que ver com o facto de a produtividade da primeira ser mais forte que a da segunda (Koefoed \& van Marle 2000) ${ }^{7}$. Por exemplo, todo e qualquer verbo com VT - $a$ é flexionado no pretérito imperfeito do indicativo com o morfema - va; todo e qualquer verbo é flexionado no pretérito imperfeito do conjuntivo com o morfema -sse. No que diz respeito à derivação, sabemos que nem todos os verbos com VT - $a$ formam nomes em -ção. Não é possível um nome como *mudação, por exemplo. Do mesmo modo, nem todos os adjetivos formam nomes de qualidade. Assim acontece com alegre >alegria, branco > brancura, amarelo >amarelidão, fácil >facilidade, mas não com angélico, eslávico ou russo.

Por último, os afixos derivacionais (cf. -iz-, -idad(e)) costumam ocorrer numa posição mais próxima do radical do que os afixos flexionais, como se verifica em agilizasse - agil+iz+a+sse (radical+afixo derivacional+vt+afixo flexional) ou em oportunidades - oportun+idad $+e+s$ (radical+afixo derivacional+it+ afixo flexional).

Exemplos como o dos z-avaliativos (sing. leão, pl. leões > leõezinhos), que se situam na fronteira com os compostos, mostram que o afixo derivativo se combina com estruturas flexionadas, contrariando assim a tendencial posição menos periférica dos sufixos derivacionais face aos flexionais (cf. cap. 9).

A designação de derivação pode ser tomada em sentido restrito, recobrindo a afixação, ou em sentido lato, equivalendo a formação de palavras. Neste caso, derivação designa qualquer processo que

7 Para a distinção entre flexão e derivação, vejam-se ainda Booij (2000), Stump (1998) e Beard (1998). 
permita formar um lexema com base noutro lexema, nela se incluindo processos como a afixação, a conversão, entre outros. É nesta aceção que derivação é usada neste livro, como já referimos inicialmente.

É através de processos derivacionais que se formam as famílias de palavras, ou mais exatamente, as famílias de lexemas (Haspelmath 2002: 14). O lexema base moral permite formar lexemas como amoral, moralidade, moralizar, imoral, moralmente.

Saliente-se ainda que a morfologia flexional é semanticamente previsível de modo absoluto, enquanto a morfologia derivacional não o é, ou só o é de modo parcial. Na secção seguinte analisaremos este aspeto.

\subsubsection{A morfologia como interface}

A morfologia mantém relações de grande interação com as demais áreas da gramática, com as quais labora em interface.

A morfologia flexional tem um papel importante na construção de frases. Em 15 a. a forma do lexema LEÃo ocorre como leão. A forma do lexema VER ocorre como viu. Em 15 b. o lexema LEÃO apresenta-se sob a forma leões e o lexema VER sob a forma viram, de modo a haver concordância sintática. $O$ mesmo acontece entre os determinantes, os nomes e os adjetivos de 15 e 16: os elefantes; as leoas furiosas; os leões furiosos. Estas marcas flexionais são, pois, importantes para a sintaxe.

(15) a. O leão viu a gazela.

b. Os leões viram as gazelas.

(16) a. Os elefantes viram as leoas furiosas.

b. Os elefantes viram os leões furiosos.

A morfologia derivacional não é exigida pela sintaxe no grau e nos termos em que o é a morfologia flexional. No entanto, 
a derivação acarreta alterações a nível da formatação sintática do lexema obtido. Por exemplo, o sufixo -ção constrói sempre nomes, enquanto -mente constrói sempre advérbios e o sufixo -ejconstrói sempre verbos. Isto significa que o lexema obtido com cada um destes afixos, ao ocorrer na frase, obedece a regras sintáticas.

Como nome, um derivado como animação não pode aparecer no cotexto de animou, o mesmo se aplicando ao advérbio agradavelmente e ao verbo amarelejar, que não ocorrem no cotexto predicativo de 18.a e de 19.a, respetivamente:

(17) a. O João animou a festa.

b. *O João animação a festa.

(18) a. O João é agradável.

b. * O João é agradavelmente.

(19) a. O papel é amarelo.

b. *O papel é amarelejar.

A morfologia mantém também uma relação privilegiada com a semântica. Como já foi observado, o conteúdo semântico gramatical do lexema é alterado através da flexão. A variação em número e em género, para os nomes e os adjetivos, e em número, pessoa, tempo, modo e aspeto para os verbos, demonstra que as mudanças na morfologia do lexema permitem alterar alguns aspetos do seu significado. A forma verei, por exemplo, localiza o evento no futuro em relação a um ponto temporal presente; a forma $v i$ localiza o evento no passado em relação ao mesmo ponto temporal.

No caso da morfologia derivacional, essa ligação entre a morfologia e a semântica é especialmente saliente. Na derivação, não estão apenas em causa alterações na semântica funcional do lexema, mas alterações na semântica lexical. Ou seja, ao construirmos, por exemplo, laranjeira a partir de laranja, estamos a designar já não o fruto, mas a árvore que o produz. A relação que a morfologia derivacional 
mantém com a semântica permite a construção de outro conceito que não o que está previsto no lexema base. Por exemplo, rato designa um animal, ratoeira um instrumento para caçar esse animal.

Repare-se ainda, comparando laranjeira e ratoeira, que os significados de cada um destes lexemas não são iguais. A despeito de serem formados com o mesmo sufixo, laranjeira não é um 'instrumento para apanhar laranjas', ou seja, não tem o mesmo semantismo de ratoeira. Do mesmo modo, ratoeira não designa, como laranjeira, 'aquilo que produz ratos'. Este aspeto mostra que a morfologia derivacional não possui uma semântica totalmente previsível, ao contrário da morfologia flexional. Esta última, porque lida com semântica funcional ou gramatical, e não lexical, é absolutamente previsível. Todo e qualquer - $v a$ adjunto a um qualquer verbo de tema em - $a$ indica o pretérito imperfeito do indicativo.

A morfologia tem também uma ligação especial com a fonologia. No caso da morfologia flexional, há mudanças fonológicas acarretadas pela colocação de um morfema. Nas formas do verbo partir, ocorrem atualizações diversas da VT. Em partis, o acento recai na sílaba -tis, o que faz que a vogal ocorra como [i] (alta e não recuada). Mas em partes, o acento recai em par-, o que leva a que a vogal postónica ocorra, no PE, como vogal alta e recuada.

$\mathrm{Na}$ morfologia derivacional também se assiste a este tipo de alteração fonológica, como é atestado pelos lexemas feliz e felicidade, impossível e ilegível. No primeiro caso, o último segmento de feliz ocorre como predorso-prepalatal não vozeado []] quando seguido de pausa ou de consoante não vozeada; como predorso-prepalatal vozeado [3] quando seguido de consoante vozeada; e como [z] quando seguido de vogal. No entanto, em felicidade ocorre como [s], ou seja, numa forma com a qual nunca ocorre em feliz. No caso de ilegível e de impossivel, estamos perante o mesmo prefixo. No entanto, esse prefixo ocorre como $i$ - quando está seguido de consoante soante (cf. Durand 1990: 168-176). 


\subsection{Constituintes}

Nesta secção descrevem-se os constituintes morfológicos do português, nas suas classes e propriedades mais salientes.

\subsubsection{Constituintes presos vs. autónomos}

Existem em português morfemas presos e morfemas autónomos ${ }^{8}$. Esta distinção baseia-se no critério formal da fixidez de posição que um morfema pode ter (os presos têm posição fixa; os autónomos não). Os morfemas autónomos correspondem a unidades que podem ocorrer, numa frase, isoladas de outras unidades que aí compareçam. As unidades com, de, já, lápis, mar, por exemplo, comportam-se como morfemas autónomos. Observemos agora as frases seguintes:

(20) O gato bebeu o leite todo.

(21) A gata tinha bebido o leitinho e as natas todas.

Utilizando operações de segmentação e de comutação, é possível destacar os morfemas gat-, beb-, leit-, tod-. Estas formas mantêm-se inalteradas mesmo quando os morfemas que lhes surgem associados são diferentes. Se tentarmos construir uma frase com estes morfemas, não se consegue a identificação das unidades em (22):

(22) *Gat beb leit tod.

8 Mattoso Câmara (1970: 69-70) faz a distinção entre morfemas presos, dependentes e livres. 
Isto deve-se a que estes morfemas, apesar de deterem a significação lexical do lexema, não podem funcionar autonomamente, ao contrário de mar, lápis, de, já, com, cor.

A mesma impossibilidade de surgirem isoladamente é visível nas unidades que separámos de gat-, beb-, leit-, tod-. Essas unidades, identificadas través das operações de segmentação e de comutação (Rio-Torto 1998a), são $-o,-a,-e,-u,-e,-i d,-i n h,-s{ }^{9}$. Comparando formas de palavras entre si, vemos que há elementos que podem destacar-se e comutar-se por outros elementos. Essas comutações acarretam alterações constantes ao nível da funcionalidade gramatical ou ao nível do significado das palavras. A segmentação e a comutação são operações essenciais à morfologia.

Sintetizando, são morfemas autónomos aqueles que podem ocorrer por si mesmos como palavras (cf. cap. 1: 1.1.2 e 1.1.3). Os morfemas presos não podem ocorrer de modo formal isoladamente. Como tal, não podem ocorrer separadamente de outros morfemas, assim como não podem mudar de posição (cf. cap. 1: 1.1.2 e 1.1.3).

\subsubsection{Radical, tema, afixo}

\subsubsection{Radical}

Formalmente, o radical é o constituinte que resta da palavra quando se extraem o constituinte temático e os constituintes flexionais (Plag 2003: 10-11).

9 O -o que surge em gato também surge em todo, o, leitinbo; o - $a$ de gata surge em natas, as, todas; o -e átono de bebeu surge em bebera, o que permite destacá-lo de - $u$ em bebeu e em comeu; o - $u$ de bebeu surge em comeu e em falou, o que permite destacá-lo de bebe-; o -e de leite surge em monte, mas já não surge em leitinho ou em montanha; -id em bebido surge em comido e comida; -inh em gatinha; -s em gatos, gatas, leites, as. 
(23) a. gato: gat-

b. andamos: and-

c. velho/a: velb-

O radical encerra a significação lexical, ou seja, conceptual: gat'pequeno felino doméstico', and- 'dar passos, caminhar; mover-se', velh-, 'que tem idade; antigo'.

Se se tratar de uma palavra complexa, como envelhecimento, o radical é o componente que se obtém retirando o constituinte temático desse lexema: envelheciment-(+-o). Trata-se de um radical complexo, ou seja, ele mesmo constituído por mais do que um constituinte morfológico: en+velh+ec+i+ment-. Semanticamente, é o radical envelheciment- que explicita a significação lexical e conceptual do lexema, que equivale a 'processo de envelhecer'.

\subsubsection{Tema e constituinte temático (CT)}

O radical mais o constituinte temático (CT) formam o tema.
(24) a. gat+o
b. adivinh+a
c. compet $+i$ (de competir)

O constituinte temático é um constituinte que se junta à direita do radical e que tem como função mostrar como é que aquele lexema se comporta em termos flexionais. Os constituintes temáticos são unidades semanticamente vazias (Aronoff 1944:44-53). Trata-se, pois, de morfemas vazios, com funcionalidade morfológica, mas não semântica.

O constituinte temático designa-se por vogal temática (VT) nos verbos e por índice temático (IT) nas restantes categorias lexicais (nomes, adjetivos, pronomes, advérbios) (Mateus \& Andrade 2000: 68). 
O quadro seguinte mostra as vogais temáticas que ocorrem em português.

\begin{tabular}{|l|l|l|}
\hline Conjugação & Vogal temática & Exemplos \\
\hline Verbos de 1. ${ }^{\mathbf{a}}$ conjugação & $-a$ & estudar, eletrificar, fidelizar, voejar \\
\hline Verbos de $2 .^{\mathbf{a}}$ conjugação & $-e$ & comer, favorecer, ruborescer \\
\hline Verbos de . $^{\mathbf{a}}$ conjugação & $-i$ & ouvir, sorrir \\
\hline
\end{tabular}

Quadro I. 2. Vogais temáticas dos verbos em português

Em suma, se um lexema é uma abstração mental do conjunto das formas de uma palavra, tem de haver um morfema que sirva de guia para que o falante saiba operar essas mudanças na forma do lexema, ou seja, na flexão. É esse o papel do constituinte temático.

O quadro seguinte mostra os índices temáticos dos nomes:

\begin{tabular}{|l|l|l|}
\hline Tema & Constituinte temático & Exemplos \\
\hline Tema em -a & IT $-a$ & casa, égua, roda \\
\hline Tema em -e & IT $-e$ & monte, leve, rede \\
\hline Tema em -o & IT $-o$ & lodo, rigoroso \\
\hline
\end{tabular}

Quadro I. 3. Índices temáticos dos nomes em português

Nem todos os lexemas do português (excluindo os verbos) apresentam constituinte temático. Muitos nomes e adjetivos dispõem apenas de radical. Diz-se destes lexemas que são atemáticos. Os nomes atemáticos disponibilizam a forma do singular com um único constituinte: o radical. Encontram-se neste conjunto dos nomes e adjetivos atemáticos os seguintes tipos:

(25) Nomes terminados no singular em /s, r, 1, n/:

a. mar: mares

b. nariz: narizes

c. azul: azuis

d. abdómen: abdómenes 
(26) Nomes terminados em vogal nasal ou oral acentuada:

a. lã: lãs

b. café: cafés

c. mó: mós

d. pá: pás

e. peru: perus

f. rubi: rubis

(27) Nomes terminados em ditongo nasal ou oral acentuados:

a. leão: leões

b. chapéu: chapéus

c. mau: maus

d. judeu: judeus

(28) Nomes terminados em -i e -u átonos:

a. táxi: táxis

b. cácu 'pardal, pássaro pequeno' (Guiné-Bissau: do crioulo guineense kacu, do mandinga káca): cácus; cálu 'refeição típica de São Tomé, confecionada com peixe seco, folhas de ocá, azeite de palma, quiabos, sal e pimenta', do forro cálu, a partir de caldo): cálus

Os singulares constituídos apenas pelo radical correspondem a lexemas atemáticos. Na formação de plural, pode surgir uma vogal epentética (Mateus \& Andrade 2000: 70), como em mares, narizes, abdómenes.

As vogais tónicas de pá, café, mó não são CT, ao contrário das vogais átonas $-a,-e,-o$, de casa, monte e pátio. Nas palavras de tema em - $a,-e,-o$, o CT não está presente na forma que serve de base a outro lexema, como é visível em:

(29) casa > casota vs. *asaota

(30) monte > montanha vs. *monteanha

(31) puro > pureza vs. *puroeza 
Em contraste com estes, em nomes como cafeeiro e cafeico mantém-se o segmento $-e$, porque este faz parte do radical (atemático) da palavra base.

A derivação avaliativa corrobora a impossibilidade de se considerarem as vogais tónicas finais como constituintes temáticos, ao contrário das vogais átonas $-a,-e,-o$.

Nas palavras terminadas em vogal tónica, como café, rubi, pó, pá, a formação de avaliativos faz-se sempre através de -z (cafezinho, pozinho, pazinha, rubizinho) e não através da avaliação sem - $z$ (*cafeinho, *poinho, *painha, *rubinho). Nas palavras de tema em -a, -e e -o, estes CT não estão presentes na forma que serve de base ao avaliativo, que prescinde, preferencialmente, de - $z$ (casinha, livrinbo, pelinho).

Em português, os lexemas nominais podem apresentar as seguintes formas de singular:

\begin{tabular}{|l|l|l|l|}
\hline Tema em -a & Tema em -e & Tema em -o & Radical \\
\hline $\begin{array}{l}\text { casa, baleia, } \\
\text { candeia, floresta }\end{array}$ & $\begin{array}{l}\text { árvore, clube, gente, } \\
\text { elefante, rede }\end{array}$ & $\begin{array}{l}\text { árbitro, boneco, } \\
\text { bolo, ramo, tribo }\end{array}$ & $\begin{array}{l}\text { mar, nariz, azul, } \\
\text { cão, } \\
\text { pó, café, animal, } \\
\text { romãa }\end{array}$ \\
\hline
\end{tabular}

Quadro I. 4. Classes temáticas de nomes em português

Quando um determinado lexema serve de origem a outro lexema, dizemos que o primeiro é o derivante ou base e o segundo o derivado ou produto derivacional. Para facilitar a leitura, é costume fazer referência ao derivante utilizando a forma citacional. Contudo, esta não corresponde ao formato do lexema que intervém como derivante de outro lexema. Por exemplo, no derivado brancura encontramos os seguintes constituintes derivacionais: $\operatorname{branc}+u r(a)$. O derivante é o lexema branco, mas o formato em que ocorre não é o do tema (branco), mas o do radical (branc-). A esse radical junta-se o sufixo derivacional -ur(a). Assim, o derivado brancura tem como base o radical do lexema BRANCO (branc-). 
Um derivado como mistificação tem por base o verbo mistificar. Mas em mistificação não encontramos a forma do infinitivo da base verbal. O que encontramos é mistifica-, ou seja, o tema do verbo, ao qual se anexa o sufixo derivacional -ção.

Já para a formação dos advérbios em -mente, a base, que é um adjetivo, tem de ocorrer na forma de tema marcado como feminino, como é demonstrado por lindamente, e não por *lindomente.

Em suma, os constituintes radical e tema são constituintes morfológicos dos lexemas, mas nenhum deles se relaciona exclusivamente com a formação de palavras, pois operam também na flexão. O formato de um lexema que serve de origem, ou seja, de base a outro lexema, no campo da morfologia derivacional, pode ser um radical, um tema ou uma palavra.

\subsubsection{Afixos flexionais}

Os afixos flexionais surgem anexados à direita do tema, quando este existe ou está presente, ou à direita do radical.

Se se tratar de um verbo de tema em $-a$, conjugado na $1 .^{a}$ pessoa do singular do presente do indicativo, o morfema flexional de número-pessoa ocorre imediatamente à direita do radical: estud+o. Se se tratar do mesmo verbo, mas conjugado na $2 .^{a}$ pessoa do singular do mesmo tempo-modo, o morfema flexional de número-pessoa surge à direita do tema, visto que a vogal temática está presente: estuda+s.

Em português ocorrem afixos flexionais que transportam diferentes cargas funcionais. No caso dos verbos regulares, estes apresentam os seguintes constituintes: radical+VT+MMTA+MNP. Porque os afixos flexionais não entram na formação de palavras, não se desenvolve neste livro esta temática, remetendo o leitor para Mateus \& Andrade (2000). 


\subsubsection{Afixos derivacionais}

Como os demais afixos, também os afixos derivacionais são constituintes presos; os afixos derivacionais agregam-se a uma base lexical formando com ela um lexema distinto do lexema que constitui essa base. Por exemplo, o afixo en- anexado à base doid(o) forma o lexema endoidar. Estes afixos são agentes ao serviço da morfologia derivacional, enquanto os afixos flexionais são agentes na morfologia flexional.

Os afixos derivacionais classificam-se segundo diferentes critérios.

Segundo a posição do afixo, mais propriamente, se este se junta à esquerda da base, à direita da base, à volta da base ou no interior da base (Matthews 1974:131; Haspelmath 2002: 19; Spencer 2015), identificam-se quatro tipos diferentes:

(i) prefixos: re+ler

(ii) sufixos: desmaquilha+nte

(iii) circunfixos: $\boldsymbol{e n}+v e l b+e c(e r)$

(iv) infixos: beberrão.

Prefixos, sufixos, circunfixos e infixos correspondem a morfemas com carga semântica. Diferente estatuto possui o interfixo (Haspelmath 2002:86; Roché 2015). Trata-se de um constituinte que é um morfema vazio, sem carga semântica (Aronoff 1994: 4445). Para uma descrição do funcionamento destes constituintes, veja-se a secção 1.6.1.

Em função da capacidade que o afixo tem de alterar ou não a categoria lexical do lexema base, os afixos são:

(i) heterocategoriais (Rio-Torto 1993: 216-229): a categoria lexical do lexema que funciona como base é diferente da categoria lexical do lexema derivado. 
(ii) isocategoriais (Rio-Torto 1993: 216-229): a categoria lexical do lexema que serve de base é igual à categoria lexical do lexema que é produzido.

Por exemplo, o sufixo -inh, se se junta a nomes, produz nomes (gato/gatinho; livro/livrinho). Se se junta a adjetivos forma adjetivos (bonito/bonitinho, novo/novinho). De modo diverso, o sufixo -osjunta-se a nomes e forma adjetivos (gas/gasoso; deleite/deleitoso); um afixo como -nci-junta-se a verbos e forma nomes (radiar/ radiância; presidir/presidência).

De acordo com a categoria lexical do lexema produzido, falamos em afixos

(i) nominalizadores, ou seja, que produzem nomes: aterr+agem; escur+idão; machad+ad(a); passar+ed(o)

(ii) adjetivalizadores, ou seja, que formam adjetivos: $\operatorname{barrig}+\boldsymbol{u d}(o / a)$; mont+ês; pavor+os $(o / a)$

(iii) verbalizadores, ou seja, que produzem verbos: dan+ific(ar); guerr+e(ar); murmur+ej(ar)

(iv) adverbializadores, ou seja, que formam advérbios: feliz+ment(e).

Em função do número de classes de base com que um afixo se combina, estes são:

(i) monocategoriais, se apenas se combinam com uma classe, como o adjetivalizador -ar, que apenas se combina com bases nominais (familiar):

(ii) pluricategoriais, se se combinam com várias classes: assim acontece com -al, que forma adjetivos denominais (industrial), nomes denominais (choupal) e nomes deverbais (estendal). 
Os afixos serão analisados detalhadamente nos capítulos consagrados à formação de nomes (cap. 2), de adjetivos (cap.3), de verbos (cap. 4) e de advérbios (cap. 6).

Interessante é estabelecer as diferenças entre os afixos e os clíticos (Matthews 1974: 217-218; Plag 2003: 72-86; Spencer 1991:350-390), dado que ambos são caraterizados por não possuírem acentuação própria.

(i) Os afixos ocorrem em posição fixa em relação à base a que se juntam (re- mantém-se à esquerda da base ler, assim como o sufixo -nte se mantém à direita da base estuda-). Em português europeu atual, os clíticos sofrem alteração na posição, de acordo com o ambiente sintático em que se situam ( $a$ Sofia deu-te o texto; a Sofia não te deu o texto).

(ii) Os clíticos anexam-se a qualquer verbo. Os afixos restringem os tipos de bases à qual se juntam. Por exemplo, os sufixos que se juntam a bases verbais não se combinam com qualquer base verbal. O sufixo -ment, por exemplo, não se anexa a verbos em -iz-ou -ific- (*helenizamento; *glorificamento).

(iii) A combinação de clítico e hospedeiro é semanticamente estável e rígida; a combinação entre afixo e base pode ser semanticamente idiossincrática (portagem designa uma 'taxa', enquanto lavagem indica um 'evento').

\subsubsection{Informações de cada constituinte}

Expostos os principais aspetos relativos aos constituintes morfológicos, sintetizamos agora os diferentes tipos de informações que cada um transporta (Villalva 2000: 179-201).

São as seguintes as classes de informação a ter em conta: 
(i) categoria lexical/sintática: verbo, nome, adjetivo, preposição, advérbio;

(ii) categoria morfossintática: género, número, tempo-modo-aspeto, pessoa-número;

(iii) categoria morfológica: radical, tema, afixo derivacional (prefixo, sufixo, circunfixo), sufixo flexional, constituinte temático;

(iv) subcategoria morfológica: paradigma de conjugação, declinação ou de qualquer nível flexional;

(v) categoria semântica: unidade de significação conceptual. Por exemplo, o morfema -ment(o) serve para formar nomes que designam 'processo' (amarelecimento).

\subsubsection{Radical}

O radical contém as seguintes informações:

\section{- Categoria lexical/sintática}

A determinação da categoria do lexema como verbo, nome, adjetivo, preposição, advérbio está a cargo do radical. Em lexemas cuja pertença a uma destas categorias parece ser apenas determinada na frase (por exemplo, olhar $\mathrm{N}$ e olhar ), assume-se que estamos perante dois radicais distintos (olb- v e olhar ${ }_{\mathrm{N}}$ ), e não perante dois radicais fonologicamente iguais. Isto significa que é no léxico que surge a determinação da categoria, a que podemos, por isso, chamar lexical e não necessariamente sintática. Em exemplos como olho e olhar $_{\mathrm{V}}$, em que fonologicamente o radical é igual (olb-), é ainda assim possível determinar que a informação respeitante à categoria se encontra no léxico, já que é no léxico que se agregam os respetivos constituintes temáticos $\left(o l b+o_{\mathrm{N}} ; o l b+a_{\mathrm{V}}\right)$. 


\section{- Categoria morfossintática}

No caso dos nomes em que o género é inerente, ou seja, em que não se faz por oposição do constituinte temático, a categoria morfossintática de género encontra-se no radical. É o caso de lexemas como mar (masculino), chão (masculino), mão (feminino), matiz (masculino), matriz (feminino). Repare-se que em chão, mão, matiz, matriz, não existe nenhum constituinte morfológico que distinga o género dos lexemas, logo o género é inerente ao radical. Também em lexemas como poeta, poema, fantasma, tribo, virago, lua, rede, monte, desenho o género é inerente ao radical.

\section{- Categoria morfológica}

O radical transporta inerentemente informação quanto à sua própria categoria morfológica, ou seja, que se trata de um radical e não de um afixo, por exemplo. Esta informação é importante devido às funcionalidades morfológicas e aos comportamentos morfológicos distintos que os diferentes constituintes possuem. Assim, por exemplo, a um radical pode juntar-se um sufixo derivacional $($ mar+inho $)$, mas a um sufixo derivacional não pode juntar-se outro

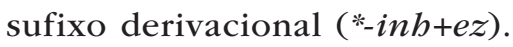

O radical pode ser preso ou autónomo. Esta classificação é sobretudo visível nos nomes e nos adjetivos, em que existem lexemas que são atemáticos, ou seja, constituídos apenas pelo radical. Lexemas como papel, amável, senhor são exemplos de radicais autónomos. Aqueles que precisam de constituinte temático são radicais presos, como os de casa, chávena, cortiça, sobreiro, couve, lindo.

No caso dos verbos, não se pode estabelecer que os radicais sejam absolutamente presos ou autónomos para cada verbo. Há formas de um verbo em que pode ocorrer apenas o radical, como faz, traz, diz, conduz, etc. Outras formas conjugadas dos mesmos verbos necessitam de outros constituintes, o que faz que o radical não surja como autónomo (fazes, trazes, dizes, conduzes). 
Assim, em teoria, os radicais verbais podem ocorrer como autónomos. Nos radicais nominais e adjetivais, a variação faz-se de lexema para lexema e não dentro do mesmo lexema.

\section{- Subcategoria morfológica}

A subcategoria morfológica diz respeito às variações formais atinentes a conjugação e declinação, enquadradas num paradigma flexional. No caso dos verbos, que detêm sempre constituinte temático, cabe a este a indicação do modo de procedimento do paradigma flexional. Quando o lexema carece de constituinte temático (lápis, réu, lã), cabe ao radical a informação relativa ao modo como se processa a variação das formas do lexema, podendo estar essa informação estruturada paradigmaticamente através de traços prosódicos, por exemplo. É este o caso da formação dos plurais de lápis e de ananás. Tendo ambos o mesmo segmento final no radical, o plural invariável de lápis correlaciona-se com a sua acentuação proparoxítona, enquanto o plural ananases se correlaciona com a acentuação oxítona do lexema. Estes dados prosódicos funcionam, pois, como indicadores que permitem o funcionamento paradigmático dos lexemas em apreço.

\section{- Categoria semântica:}

Como se disse em 1.2.2.1., o radical contém a informação conceptual acerca do referente.

\subsubsection{Constituinte temático}

\section{- Subcategoria morfológica}

O constituinte temático é o constituinte que, quer no verbo (vogal temática), quer nas restantes categorias lexicais (índice temático), carrega a informação relativa à subcategoria morfológica a que o lexema pertence. A subcategoria morfológica diz respeito 
à conjugação, no caso dos verbos, e, no caso dos nomes e dos adjetivos, à declinação (nas línguas em que existe variação formal de caso) e à variação em número. Como já vimos, é a presença do constituinte temático que indica como proceder à conjugação de determinado verbo (reflita-se sobre o exemplo dos verbos falar e falir ou remar e remir). Num adjetivo como inteligente, o índice temático -e mostra como construir o plural.

\section{- Categoria morfossintática}

No caso dos nomes cujo radical não possui género inerente, está a cargo da oposição entre dois constituintes temáticos a distinção, neste caso, morfológica, do género. Exemplos: gato/gata; menino/ menina. $\mathrm{O}$ mesmo é válido para os adjetivos que admitem este tipo de oposição formal, como lindo/linda; prático/prática. Repare-se que não podemos dizer que -o/- $a$ são morfemas de género. Se assim fosse, todos os nomes em -o seriam masculinos e todos os nomes em - $a$ seriam femininos. Ora, essa relação não se verifica, como é mostrado por exemplos que já vimos nesta secção e que aqui repetimos: tribo, virago são femininos; poeta, fantasma, fonema são masculinos.

Assim, a informação sobre o género (i) pode estar no radical e não ser apontada pelo constituinte temático (céu; caderno; estrela; homem; mulher); (ii) pode ser veiculada pela oposição entre dois constituintes temáticos que se juntam ao mesmo radical (menino/menina).

Note-se que, em caso e casa, não há oposição de género do mesmo modo que há em menino/menina. Ao contrário deste último par, em que ao mesmo radical se junta um índice temático que permite a oposição de género, em caso e casa estamos perante dois radicais distintos.

\section{- Categoria morfológica}

O constituinte temático em si mesmo contém a informação de se tratar de um constituinte temático e não, por exemplo, de um afixo 
flexional. A vogal temática - $a$ de estudar não se confunde com o afixo flexional de tempo-modo-aspeto $-a$ do presente do conjuntivo dos verbos de $2 .^{\mathrm{a}}$ e de $3 .^{\mathrm{a}}$ conjugações (leia).

O constituinte temático é um morfema preso.

Dado que o tema é constituído pelo radical e o constituinte temático, o tema apresentará as informações que em conjunto os dois constituintes contêm.

O tema pode ocorrer autonomamente tanto nos verbos (fala, escreve) como nos adjetivos (amarelo, orgulhoso, quente) e nos nomes (preconceito, aventura, monte).

\subsubsection{Afixos derivacionais}

Apresentam-se de seguida as categorias dos afixos derivacionais.

\section{- Categoria morfológica}

Os afixos derivacionais contêm informação acerca da categoria morfológica a que pertencem. Como afixos derivacionais, têm capacidade de gerar novos lexemas, quando anexados a uma base lexical. No entanto, ao contrário dos radicais e dos temas, os afixos derivacionais não podem servir de base a um lexema, ou seja, não se lhes pode juntar um afixo derivacional de modo a formar lexema: ${ }^{-}$-il+-idade ${ }^{10}$.

Os afixos derivacionais podem ser prefixos, sufixos, circunfixos e infixos. Os interfixos não têm em português capacidade derivacional, mas são antes uma consequência fonológica da afixação e da composição, como veremos em 1.6.1.4.

A posição em que ocorrem em relação à base encontra-se formatada na sua categoria morfológica. O prefixo ocorre sempre à esquerda

$10 \mathrm{Em}$ formações do tipo (os) prós, (os) contras, os afixos estão lexicalizados como nomes. 
da base: re-+ler; des-+caroçar; *caroçar+des; *ler+re. O sufixo ocorre à direita da base: casa+ment(o); estend+al; figu+eir (a); *ment+casa; *al+estend; *eir+figu. Observe-se que o índice temático, bem como os afixos flexionais, não são tomados em conta para efeitos derivacionais.

O circunfixo é caraterizado por ser descontínuo. Uma parte do circunfixo ocorre à esquerda da base; a outra parte à direita. O estatuto de circunfixo deve-se ao facto de as duas partes serem anexadas à base em simultâneo. O exercício de segmentação clarifica este aspeto: um lexema como envelhecimento tem por base uma base, que é envelheci-, e um sufixo derivacional -ment-. O sufixo -ment- é anexado à base isoladamente. Atentemos agora no lexema envelhecer. Não é possível considerar o elemento en-como prefixo que se anexasse à base inexistente *velhecer, pois esta base não ocorre em português. Também não podemos considerar que -ecse anexou como sufixo à base *envelh(ar), visto esta também não ocorrer. A única forma de explicar envelhecer é considerar que o elemento da esquerda e o da direita foram agregados à base velh(o) em simultâneo e não sequencialmente.

$\mathrm{O}$ infixo ocorre no meio da base ou entre a base e o sufixo sem lugar a introdução sequencial, como em gatarrão.

Os interfixos (cf. cap. 1: 1.6.1.4) ocorrem entre a base e outra base, no caso da composição (rabirruivo) ou entre a base e o sufixo derivacional (cãozinho) e não possuem carga semântica.

Os afixos derivacionais, assim como os afixos flexionais, são morfemas presos.

Ao contrário dos afixos flexionais, os afixos derivacionais possuem restrições de seleção das bases a que se anexam.

\section{- Categoria lexical}

Os sufixos derivacionais determinam a categoria lexical do lexema derivado. Não há contradição entre isto e aquilo que dissemos a respeito do radical. Dissemos que a categoria lexical se encontra 
especificada pelo radical. Ora, não podemos esquecer que o sufixo derivacional faz parte do radical do lexema derivado. Assim, em envelhecimento, o sufixo -ment- constrói o lexema derivado como nome. O radical é envelheciment-, ou seja, inclui o sufixo derivacional. O sufixo -ec- constrói o produto como verbo (ruborescer).

\section{- Categoria morfossintática}

Alguns afixos derivacionais carregam informação morfossintática. Por exemplo, o sufixo -ção categoriza o produto que é por ele formado como de género feminino (a destruição, a avaliação). Quanto aos verbos, não existe nenhum sufixo derivacional que forme verbos que tenha a seu cargo as categorias morfossintáticas de modo-tempo-aspeto ou de número-pessoa.

\section{- Categoria semântica}

Os afixos derivacionais possuem informação sobre a categoria semântica. Os lexemas avaliador e avaliação têm por base o verbo avaliar. A marca semântica de cada um dos sufixos, -dor e -ção, é que contribui para que as significações de avaliador e avaliação sejam, respetivamente, as de 'pessoa que avalia' e 'evento de avaliar'.

\section{- Subcategoria morfológica}

No caso em que o afixo derivacional precisa de um constituinte temático para construir o lexema (ceif-eir-a; cart-eir-o), em si mesmo esse sufixo não possui subcategoria morfológica, pois não indica por si só a que tema ou a que conjugação pertence o lexema. Contudo, cada sufixo possui capacidade de determinar qual o constituinte temático que se vai juntar ao radical para formar a palavra. Por exemplo, os sufixos verbalizadores -iz- e -ific- vão ter à sua direita a vogal temática $-a($ mum $+i f i c+a(r)$; arbor+iz+a(r)). Os sufixos -esc- e -ec- vão ter à sua direita a vogal temática -e (rubor+esc+e(r); amarel+ec+e(r)). O sufixo nominalizador -dur-vai ter à sua direita 
o índice temático - $a($ borda $+d u r+a ;$ cavalga $+d u r+a)$, enquanto o sufixo nominalizador -ment- ocorre com o índice temático -o (diverti+ment+o; congela+ment+o). Existem sufixos que admitem a variação da vogal temática. É o caso de -dour- (mata+dour+o; $d o b a+d o u r+a)$, -eir- (flor+eir+a; cart+eir+o), entre outros. Vemos, pois, que a subcategoria morfológica não é interna ao sufixo derivacional, se este precisar de ocorrer com constituinte temático. No caso dos sufixos que não preveem a ocorrência de constituinte temático - o que não se verifica nos verbos - a subcategoria morfológica é inerente ao sufixo. É o caso de -ês (francês, montês), -vel (agradável, desmontável), entre outros.

Será evidenciado cada um dos tipos de operadores na secção 1.6, onde se explicitarão aspetos dos diferentes processos de formação de palavras.

\subsubsection{Afixos flexionais}

\section{- Categoria morfossintática}

Os afixos flexionais disponibilizam informação acerca da categoria morfossintática. Os morfemas de modo-tempo-aspeto mostram estes três dados relativamente aos verbos.

Os morfemas de número permitem flexionar o lexema nominal e adjetival em plural. Quanto à categoria morfossintática de género, já foi referido que, em português, o género pode ser mostrado morfologicamente através da oposição -o/- $a$. Nos restantes casos, ou seja, naqueles em que não se observa mudança de género formal através desta oposição, a categoria do género não está a cargo de mecanismos de flexão.

Nas línguas com flexão em caso, os morfemas respetivos codificam esta categoria morfossintática. Em português, apenas o pronome pessoal mostra flexão em caso. 


\section{- Categoria morfológica}

Os afixos flexionais transportam internamente informação quanto à sua própria categoria morfológica, ou seja, quanto ao facto de serem afixos flexionais. Isto leva a que um afixo flexional, quando agregado a um tema ou a um radical, não dê origem a um novo lexema, mas a uma forma de palavra do lexema fletido, ao contrário dos afixos derivacionais. Para além disso, como afixos flexionais, a sua categoria apenas lhes permite ocorrer à direita do radical ou do tema, quando este ocorre. A própria ordem em que ocorrem os afixos flexionais entre si é fixa. Nos verbos, a ordem é Rad+VT+MMTA+MNP. A sua categoria morfológica obriga a que os afixos flexionais ocorram à direita dos afixos derivacionais.

Os afixos flexionais, bem como os derivacionais, são morfemas presos.

Os afixos flexionais não apresentam restrições de seleção em relação às formas a que se juntam. Por exemplo, o morfema -mos de número-pessoa agrega-se a qualquer verbo. Pelo contrário, os afixos derivacionais mostram restrições de seleção. Por exemplo, o sufixo -ção, que se junta a verbos para formar nomes, não se anexa a verbos que tenham o sufixo -esc- ou -ec- (*amareleção; *ruboresceção).

\subsection{Palavras simples vs. palavras complexas; palavras derivadas vs. não derivadas}

As palavras simples contrapõem-se geralmente às complexas e as derivadas às não derivadas. No entanto, há palavras cuja estrutura (e cuja formação) acusa interseção entre as dimensões da simplicidade/complexidade e da derivacionalidade/não derivacionalidade da sua estrutura e da sua génese.

Assim, as palavras simples podem ser não derivadas, mas também podem ter sido formadas por derivação/conversão. Em paralelo, 
uma palavra complexa pode ter sido formada por derivação, mas também pode ser não derivada.

Designam-se por palavras simples aquelas que possuem como constituintes morfológicos apenas o radical e o constituinte temático ou apenas o radical. Esse radical é também ele simples, ou seja, não é divisível em mais morfemas. Por exemplo, mar é um radical simples e em simultâneo uma palavra simples. Casa, constituído por radical simples e constituinte temático, é uma palavra simples.

São palavras complexas as que apresentam, para além destes constituintes, outros morfemas, como afixos derivacionais (Plag 2003: 10). Podem existir radicais complexos, ou seja, constituídos por mais do que um morfema. Por exemplo, a palavra gatil é um radical complexo, na medida em que é constituído pelo radical da palavra que lhe deu origem (gat-) mais o sufixo derivacional (-il). A palavra encadernação é uma palavra complexa que corresponde

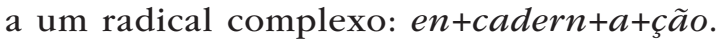

A distinção entre simples e complexo tem que ver com a existência na palavra de mais do que um morfema (excetuando o constituinte temático cuja presença não faz da palavra uma palavra complexa). Esta distinção não se prende, assim, com o caráter derivado ou não derivado do lexema. Quer isto dizer que podemos ter palavras simples que são derivadas; assim como podemos ter palavras complexas que são não derivadas.

A distinção entre o caráter derivado vs. não derivado do lexema apoia-se na possibilidade de o lexema ser construído em português, ou seja, de obedecer aos parâmetros formais e semânticos de formação de palavras que estão disponíveis em português. Quer isto dizer que mesmo que um lexema apresente correspondente em latim, se esse lexema mostrar constituintes morfológicos e um padrão de construção ativos em português, é considerado derivado (Rodrigues 2008: 121-128). Não se pretende com esta visão anular o caráter histórico da língua, ou esquecer o percurso que liga o latim ao português. Pretende-se 
enfatizar o papel ativo que a mente do falante tem na construção dos lexemas, bem como na sua análise em constituintes que se mantêm atuais sob o ponto de vista da sua capacidade derivacional.

Por exemplo, um lexema como dedicação, a que corresponde o nome latino DĒDǏCĀTǏONE-, é suscetível de ser classificado como derivado. À luz do padrão que constrói nomes que designam 'ação' a partir de verbos através do sufixo -ção, dedicação está perfeitamente enquadrado nos parâmetros de formação de palavras do português.

Consideram-se palavras derivadas aquelas que mostram constituintes morfológicos (radical, tema, afixos) existentes em português, bem como a obediência aos padrões de formação de palavras do português.

Designam-se por palavras não derivadas aquelas (i) cujos constituintes morfemáticos não são identificáveis com morfemas ativos do português; (ii) ou que não apresentam uma relação de derivadas com um lexema do português; em suma, que não obedecem aos parâmetros de formação de palavras desta língua.

Por exemplo, gato é uma palavra não derivada por não manter uma relação de derivada com outro lexema do português. Já o nome gatil é derivado d(o radical d)e gato.

Observemos agora as palavras complexas não derivadas. Um lexema como conceber é um lexema complexo, porque constituído por mais do que um morfema $(c o n+c e b)$, mas não derivado. O constituinte -ceb- não tem autonomia em português para servir de radical a novas formas e dificilmente se consegue delimitar a significação de -ceb-, apesar de -ceb- ocorrer noutros lexemas, como receber, perceber. Palavras deste tipo, como também aferir, conferir, referir, deferir, são constituídas por vários morfemas (con-+-ceb-; re-+-ceb-; per-+-ceb-; $a$-+-fer-; con-+-fer-; re-+-fer-; de-+-fer-), que conseguimos destacar através da comparação e identificação com outros morfemas existentes noutros lexemas. Contudo, os constituintes -fer- e -cebnão estão disponíveis em português para criar novos lexemas. Para além disso, a significação desses morfemas nem sempre é linear. 
Por este motivo se diz que estes constituintes são opacos e não transparentes (Rodrigues 2008: 124-127).

É constituinte opaco aquele cuja significação não se encontra clara na sincronia atual da língua. Conceber, receber, perceber. A sua identificação como morfema faz-se formalmente por segmentação e identificação noutros lexemas da língua.

É constituinte transparente aquele que, para além de ser identificável formalmente como uma unidade morfológica da língua, pela comparação entre vários lexemas que o contêm, apresenta uma carga semântica claramente identificável: reler, amigável, impossível, amoral.

Por fim, observemos as palavras simples e simultaneamente derivadas/conversas. Uma palavra pode ser simples e em simultâneo ser derivada em português. É o caso dos nomes e dos verbos derivados por conversão (cf. cap. 2: 2.4 .3 e cap. 4: 4.1 .2 e 4.3.3.1, respetivamente). Um nome como abraço é derivado do verbo abraçar. Contudo, para a sua formação não foi utilizado nenhum afixo derivacional e, como explicaremos em 1.6.3, o constituinte temático não faz duma palavra uma palavra complexa. Logo, a presença do constituinte temático -o em abraço não faz que o lexema seja complexo. Para que o produto fosse complexo, necessitaria de ter um radical complexo $\left([\text { cabel }]_{\mathrm{RN}}\right.$,

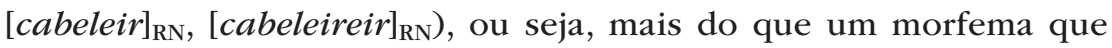
não o constituinte temático (no caso $o / a$ ). O mesmo ocorre nos verbos conversos a partir de nomes, como em açucarar, formado a partir do radical açúcar. O quadro seguinte sintetiza a classificação proposta:

\begin{tabular}{|l|l|l|}
\hline & Palavras simples & Palavras complexas \\
\hline Palavras não derivadas & $\begin{array}{l}\text { casa, belo, gente, } \\
\text { amar, ouvir }\end{array}$ & aceder, conferir, receção, translação \\
\hline Palavras derivadas & $\begin{array}{l}\text { abraço, remendo, } \\
\text { olear, açucarar }\end{array}$ & $\begin{array}{l}\text { caseiro, encadernação, guloso, } \\
\text { generosamente, refazer, tranquilidade }\end{array}$ \\
\hline
\end{tabular}

Quadro I. 5. Classes de palavras: simples, derivadas, complexas e não derivadas 
Face ao exposto, depreendemos que a formação de palavras não se rege apenas pela constituição em morfemas, mas antes pela estruturação em paradigmas (Anderson 1992; Beard 1995), e que a constituição em morfemas não acarreta que o lexema seja derivado.

A análise empírica da organização interna de algumas palavras evidencia que:

a) o morfema, como definido no início deste capítulo, é uma unidade mínima com função na gramática da língua, e não uma associação biunívoca entre uma forma e um significado (Aronoff 1994). Pode um significado ser veiculado por duas formas em simultâneo (circunfixação), pode um significado ter uma forma com funcionalidade e não significado (cf. expletividade 1.1.3.1), pode um significado/uma função ser veiculado/a por formas diferentes (alomorfia). Pode um morfema, como um constituinte temático, ter funcionalidade não semântica, mas gramatical.

b) há variações morfológicas que não têm um morfema responsável (conversão). A morfologia não é uma organização que labora obrigatoriamente com morfemas. A morfologia pode organizar-se através de paradigmas e relações entre paradigmas (Anderson 1992; Beard 1995; Rodrigues 2016). O facto de se encararem estas alterações como do domínio da morfologia prende-se com as mudanças formais que essas alterações acarretam (o [açúcar] ${ }_{\mathrm{RN}}$, os $[\text { açúcar }]_{\mathrm{RN}} e s ;[\text { açucar }]_{\mathrm{RV}}$ ar, eu açucaro, tu açucaras).

\subsection{Segmentação e comutação}

Reflete-se nesta secção sobre a importância das operações de segmentação e de comutação para a identificação de morfemas (Plag 2003: 74-78; Rio-Torto 1998a; Schmid 2015). 
$\mathrm{Na}$ língua existem segmentos ou sequências de segmentos que, pela sua repetição noutras unidades, são interpretáveis como unidades morfológicas. A repetição formal não é, no entanto, suficiente para que se considere estarmos perante um morfema. É necessário que a esse constituinte esteja aliada uma carga semântica ou funcional. No caso dos radicais e dos afixos derivacionais a carga será semântica; no caso dos afixos flexionais, dos interfixos semanticamente vazios e dos constituintes temáticos será funcional. Dentro destes três tipos, o constituinte temático e o interfixo destacam-se por possuírem uma funcionalidade puramente morfológica, sendo morfemas vazios (Aronoff 1994: 44-45). Já os afixos flexionais têm uma função de interface semântica e sintática. Em todo o caso, os segmentos a destacar possuem um papel na língua que não se restringe à fonologia.

Observemos os exemplos: reler, remar, rever, regar, regalar, reificar, rejeitar, renascer, todos iniciados pela sequência re-. No entanto, em alguns, re- é apenas uma sequência de fonemas (32 b), enquanto noutros re- apresenta uma carga semântica que contribui para o todo semântico do lexema (32 a).

(32) a. reler, rever, renascer

b. remar, regar, regalar, reificar, rejeitar.

Para além disso, se retirarmos re-aos lexemas de (32 b), estes ficam desprovidos de significado, na medida em que re- não é uma unidade, nem a parte restante outra unidade a que o primeiro se pudesse juntar ("mar; "gar; "galar; *ificar; *jeitar). Nos lexemas em que re-é um morfema (32 a), a sua supressão deixa intacta outra palavra, que é a base à qual re-se juntara (ler, ver, nascer).

Repare-se que as sequências obtidas de 32 (b) *mar, *galar não se confundem com o nome mar 'extensão de água', nem com o verbo galar 'realizar coito com a fêmea (a ave macho)'. Esta não 
identificação deve-se ao facto de não haver coincidência semântica entre os segmentos de remar e regalar com mar e galar.

Já em ler, ver, nascer, a supressão de re- dá lugar a palavras que têm uma relação semântica com as formas que contêm re-.

A morfologia opera desta forma: comparam-se paradigmaticamente segmentos e sequências de segmentos entre si de modo a perceber se se trata de unidades morfológicas, ou seja, que têm um papel semântico ou funcional na língua, ou se se trata apenas de um fonema ou de uma série de fonemas desprovidos de caráter morfológico.

Quando dizemos que a morfologia opera desta forma, falamos da morfologia não apenas enquanto área de estudo, mas também enquanto estrutura mental que o falante possui e que lhe permite combinar os constituintes morfológicos da sua língua, de modo a fazer variar o lexema cotextualmente (morfologia flexional) ou a construir outros lexemas com base num lexema (morfologia derivacional) (Jackendoff 2002: 155-158; Rodrigues 2015).

A relevância destas considerações avulta na aquisição e no desenvolvimento da componente morfológica da língua materna, pois estes fazem-se à luz de tais operações. A criança, nos primeiros contactos com a língua materna, está perante um todo não segmentado. A tarefa a que irá proceder gradualmente consiste na identificação de segmentos e de sequências de segmentos que se repetem formalmente, mas mantendo também a carga semântica/ funcional. Imaginemo-nos perante um texto numa língua que desconhecemos. O primeiro contacto é opaco, mas se tentarmos com alguma atenção comparar palavras que aparecem no texto, vemos que há elementos que se repetem, outros que se repetem com alterações formais. Se nos expusermos a essa língua, ao fim de algum tempo conseguimos identificar morfemas, ou seja, conseguimos relacionar paradigmaticamente formas com cargas semânticas/ funcionais, de modo a conseguirmos construir implicitamente inferências acerca do seu funcionamento. 
Numa segunda fase, a criança vai aprender os constrangimentos que existem entre a combinação desses morfemas. Por exemplo, vai aprender que com a base vermelho ocorre o sufixo -idão e não -ez (vermelhidão vs. *vermelhez), mas que com a base robusto ocorre -ez e não -idão (robustez vs. *robustidão). Também esta aprendizagem é implícita e não explícita, ou seja, o falante não sabe explicitar os motivos destas ocorrências. É papel da morfologia enquanto área da linguística explicitar estes padrões que são construídos na mente do falante de modo implícito.

Contudo, existem morfemas cuja identificação não é tão clara como nos casos que temos vindo a observar. Há morfemas cujas fronteiras são de difícil identificação. Atentemos em exemplos como maioridade, beldade, amabilidade, ou ainda professor, cantor, comunicador. Há nestes exemplos uma variação formal, embora haja consistência semântica entre as várias formas.

\subsection{O léxico mental: criatividade e produtividade}

\subsubsection{O léxico mental}

Esta organização de estruturas de palavras tem lugar na mente do falante de modo dinâmico (Jackendoff 2002: 152-195). Esse caráter dinâmico implica que o falante analise essas estruturas e as utilize para formar novas palavras. Mesmo as palavras atuais não estão necessariamente fixas no léxico, pelo que podem ser 'montadas' online cada vez que o falante fala. Isto significa que um lexema como avaliação não é necessariamente um bloco que se encontre rígido e indecomponível na memória do falante. O falante pode fazer a montagem do lexema em cada ato de fala. Para isso, o falante recorre aos mecanismos paradigmáticos, às bases e 
aos operadores afixais disponíveis para formar nomes deverbais de 'ação'. Escolhe a base que encerra o significado conceptual que pretende exprimir e para essa base escolhe o afixo que obedece aos constrangimentos que a base e o padrão derivacional impõem.

É vulgar, num ato de fala, que o falante hesite entre dois afixos e acabe por colocar o afixo menos habitual na companhia daquela base. A hesitação entre afixos mostra que os lexemas derivados não se encontram fixos no léxico. São antes montados online. Por exemplo: com a base encaderna( $r$ ), pode assistir-se a uma hesitação entre o sufixo -ção (34) e o sufixo -ment- (33):

(33) O encadernamento do livro saiu caro.

(34) A encadernação do livro saiu cara.

Se o lexema derivado fosse um bloco rígido inscrito como tal na mente do falante, não haveria este tipo de hesitação.

O dinamismo da morfologia é bem visível no campo da flexão. Os verbos em português são conjugados em 6 pessoas, em 10 tempo-modos simples, a que se juntam 2 formas para o imperativo e 3 formas para o gerúndio, infinitivo impessoal e particípio. Cada verbo tem portanto 65 formas diferentes. Se pensarmos no número de verbos da língua, que será infinito, dada a possibilidade de construirmos novos verbos, vemos que teríamos um número infindável de formas de palavra para memorizar como blocos rígidos. Se, pelo contrário, na nossa mente estiverem os padrões que permitem fazer essas alterações formais ativamente, online, vemos que a morfologia, em vez de ser uma listagem infindável de formas, é antes um mecanismo versátil de adequação do lexema ao cotexto e de criação de novos lexemas com base em recursos finitos (Jackendoff 2002:163-165; Rodrigues 2015; 2016).

Obviamente que a memória tem um papel importante na construção destes padrões e mesmo na averiguação, por exemplo, na 
morfologia derivacional, de qual a forma mais usual. Mas a opção por uma dada forma como mais usual passa pela escolha da forma mais conforme aos padrões derivacionais. Não obstante, a memória tem um papel determinante, na medida em que as formas mais usadas são aquelas que têm uma inscrição mais sólida na memória (Plag 1999: 51-52; Plag 2003: 65-66; Rainer 1988). Portanto, mesmo lexemas construídos através de padrões produtivos podem estar armazenados na memória, se forem de uso frequente. O interessante é que para interpretarmos um lexema novo não precisamos de o ter armazenado na memória. Isto prova que a construção de padrões morfológicos é determinante na relação do falante com a morfologia da sua língua.

O léxico não é, assim, uma listagem de lexemas fixos em número finito. Por um lado, há a considerar a criação de novos lexemas com base nos recursos derivacionais existentes na língua. Por outro lado, os lexemas atuais não são necessariamente blocos rígidos de componentes inscritos solidificados na memória. A sua atualização pode passar pela montagem online entre os componentes morfológicos que o constituem de acordo com os padrões do português. É pelo facto de estes padrões estarem ativos que é possível continuar a formar novos lexemas com base nos mesmos padrões. Se os padrões fossem meras descrições que o linguista utilizasse para dissecar os lexemas e não correspondessem a parâmetros de uso real por parte do falante, não seria possível ao falante continuar a criar novos lexemas, usando esses mesmos parâmetros.

É isto que explica a possibilidade de criação de um lexema como euripidização num enunciado como a euripidização da tragédia.

Os nomes em -ção são formados a partir de verbos. Imaginese que este é o primeiro enunciado em que surge o lexema euripidização e que em nenhum outro se introduziu o verbo euripidizar. Podemos dizer que, pelo facto de euripidização 
surgir cronologicamente primeiro e euripidizar depois, estamos perante um caso de derivação regressiva? Ou seja, retirou-se o sufixo -ção para se obter euripidizar? A resposta é negativa. Se a base de euripidização é o tema verbal euripidiza-, mentalmente teve de se gerar primeiro o verbo euripidizar e, a partir deste, o nome deverbal euripidização. Significa isto que o léxico mental tem capacidade de gerir estas estruturas de forma dinâmica. Estes lexemas são lexemas potenciais, ou seja, embora não atestados, obedecem aos padrões de formação de palavras do português.

A formação de lexemas não atestados é muito comum por parte da criança, no período em que constrói indutivamente as regras derivacionais da sua língua (Clark \& Clark 1979). Uma criança que diga clipar no sentido de 'prender com clipe', não está a dizer nenhum disparate ou erro linguístico. Está a praticar o seu conhecimento morfológico, à luz do padrão que permite criar ancorar com base em âncora, alfinetar com base em alfinete, agrafar com base em agrafo, martelar com base em martelo. A criatividade alia-se à construção de um conhecimento implícito do funcionamento da língua.

No âmbito da morfologia flexional, o facto de a criança produzir fazi ou trazi, em vez de fiz e de trouxe, mostra que a construção dos padrões de flexão está a ser processada dinamicamente. A partir dos padrões regulares, a criança aprende implicitamente que basta juntar $-i$ ao radical do verbo de tema em - $e$ para termos a $1 .{ }^{a}$ pessoa do singular do pretérito perfeito do indicativo: com $+i, b e b+i, c o m b a t+i$. Um conhecimento mais completo da língua deixar-lhe-á ver, posteriormente, outros padrões flexionais que lhe permitirão dizer fiz e trouxe.

$\mathrm{O}$ papel da memória é aqui visível. $\mathrm{O}$ adulto tende a usar as formas mais frequentes (trouxe, fiz), ou seja, aquelas que estão mais armazenadas na memória.

O léxico é constituído então por formas fixas e por padrões que permitem gerar novas formas. Das formas fixas fazem parte os lexemas não derivados (casa, gato, cão, amarelo, triste, amar, 
correr, mas, sim, não, etc.) e os morfemas (re-, -s, -va, -ção, -a, etc.). Dentro das formas fixas é possível que se encontrem lexemas derivados com um uso muito frequente (avaliação, contentamento, envelhecer, solidificar), bem como os lexemas derivados produzidos com um padrão pouco produtivo (queimor, tapume).

Se considerarmos estes dois fatores - alta frequência e pouca produtividade - em simultâneo, os lexemas derivados que os apresentam deverão ser aqueles, dentro dos derivados, que mais suscetíveis são a estarem armazenados na memória. Isto significa que não é possível determinarmos completamente quais os lexemas que estão armazenados na memória.

Se esse fator depende da frequência, esta dependerá do próprio falante. Imaginemos um falante que lide com o domínio da economia. Este falante poderá ter na memória de modo mais acessível o lexema cartelização. Um falante que não lide com este domínio pode não ter na memória já disponível cartelização. Repare-se que não estamos a referir a capacidade de cada falante recordar o significado de cartelização, mas de aceder ao formato cartelização já montado. Pressupomos neste exemplo que ambos os falantes conhecem a base cartel 'acordo entre empresas do mesmo setor com o objetivo de monopolizar o mercado'. O falante economista está acostumado a usar o lexema cartelização como um todo. O falante não economista conhece o termo, ou conhece cartel, mas, como não usa o primeiro frequentemente, não o tem disponível como um bloco na memória. Recorre então aos padrões de formação de palavras para construi-lo.

\subsubsection{Produtividade e criatividade}

Se analisarmos a constituição morfológica de nomes deverbais do português, vemos que existem vários sufixos que servem o propósito de gerar nomes com base em verbos (35). 
Dos sufixos apresentados, alguns, como -ção, continuam disponíveis para a formação de novos lexemas (carceriza+ção). No entanto, -or, presente em queimor, não se mostra disponível: *alegror (que teria por base o radical verbal de alegrar).

Os padrões que continuam a ser usados são os padrões produtivos. Os padrões que não são usados atualmente são não produtivos.

A produtividade, sobretudo na morfologia derivacional, é um parâmetro gradativo. Os exemplos de nomes deverbais antes observados mostram sufixos totalmente produtivos (-ment-, -ção) e um exemplo com produtividade mínima, que é o sufixo -or. $\mathrm{Na}$ verdade, o exemplo como queimor impede que se considere este sufixo como improdutivo. Mas a impossibilidade de gerar *adoror, *ustor, *detestor, *odior, com base em verbos (adorar, ustir 'estimar, retribuir; reg. suportar, queimar', detestar, odiar) que apresentam as mesmas caraterísticas semânticas e argumentais daqueles que estão na base de ardor, amor, queimor (arder, amar, queimar), mostra que -or não tem grande grau de produtividade.

O mesmo ocorre com o sufixo -um(e) que se apresenta nos seguintes nomes deverbais: ardume (arder), corrume (correr), curtume (curtir), queixume (queixar), tapume (tapar) e urdume (urdir). Se quisermos produzir um nome deverbal, tenderemos a usar -ment-, -ção, - ão, entre outros, mas não -or nem -um-.

A produtividade é um mecanismo inconsciente. $\mathrm{O}$ falante põe em prática a competência morfológica que possui, ou seja, os padrões morfológicos e gera um lexema ou uma forma de palavra, no caso da morfologia flexional, sem que tenha consciência de que está a produzir uma forma nova. 
A criatividade é já um modo consciente de gerar o lexema. Não se aplica à morfologia flexional. No caso de eduquês, criado por Marçal Grilo, consegue-se até especificar o criador do lexema. Mas em outros casos assim não é, como terá acontecido com Cavaquistão 'território de intensa base eleitoral de Cavaco (Silva)', criado no período em que este foi primeiro ministro de Portugal (1985-1995), com Kadafistão [de Kadafi, presidente da Líbia de 1977 a 2011] (http://blasfemias.net/ 2011/03/12/a-democracia-libia-nao-tarda/, Posted 12 março, 2011), com (PB) Lulistão (de Lula, presidente do Brasil de 2003 a 2011] (ouvido no PB), em analogia com nomes de países como Tajiquistão ou Uzbequistão.

Um cómico português, Raul Solnado, criou na época de sessenta os neologismos lisboagens e aerolisboa, para contrastar com a reanálise que fez de portagens e de aeroporto, relacionando estes dois últimos nomes com o topónimo Porto, que coincide fonologicamente com o radical port- neles presentes. No programa humorístico, realizado na cidade do Porto, fazia humor com o facto de Lisboa pagar portagens e ter um aeroporto (até então inexistente no Porto), sem que o Porto pagasse lisboagens e sem que tivesse um aerolisboa. $\mathrm{Ou}$ seja, foram criados estes neologismos por analogia com os padrões vigentes de formação de nomes, mas trata-se de criações efémeras que não perduram no uso comum.

A formação de palavras deve ser entendida:

(i) como o domínio de geração dinâmica e em linha, na mente de cada falante, de palavras já existentes na língua. Enquadrase neste âmbito a montagem dinâmica mental de vocábulos como cartelização, financeirizar ou inventividade que, sendo de uso pouco frequente num dado indivíduo, não se encontram disponíveis em memória como objetos já montados. O falante recorre, assim, aos mecanismos disponíveis na sua língua e através deles gera o lexema. 
(ii) como o domínio de geração de novos lexemas ainda não existentes na língua. Tal como no caso anterior, o falante serve-se dos parâmetros e dos materiais linguísticos da sincronia da sua língua para gerar novas palavras. Nesta situação, encontram-se, por exemplo, antibiotizar ou troikizar (atuar em conformidade com a troika, denominação do conjunto de três negociadores, representantes do Banco Central Europeu, da Comissão Europeia e do Fundo Monetário Internacional, na negociação das dívidas da Irlanda, de Portugal e da Grécia), criados ad hoc para este texto.

Os motivos que levam à geração de novas palavras prendem-se com fatores referenciais, sintáticos e avaliativos.

Os fatores referenciais relacionam-se com a necessidade de denominar um novo objeto da realidade ou um objeto nunca antes identificado. Bastará pensarmos que antes da descoberta da penicilina por Alexander Flemming não existiria o termo antibiótico. É este também o caso de troikização, se o falante pretender nomear a influência da troika em algum setor da sociedade portuguesa, durante o período de supervisão daquela.

Mas nem sempre a geração de lexemas é motivada pela existência de novas realidades. Muitas vezes, ela é imposta por necessidades de combinatória sintática. Assim, para significar 'ministrar antibiótico' gera-se o verbo antibiotizar. A realidade converge no mesmo objeto, mas a construção sintática promove um novo lexema.

A criação de lexemas pode também advir da necessidade de expressão de atitudes, juízos de valor em relação aos seres ou aos objetos. Se um falante, para referir uma família de apelido Coco, disser Veio a Cocaria toda, revela uma atitude pouco favorável em relação ao referente.

Repare-se que muitas vezes estas formações ocorrem apenas em círculos fechados e sem extensão de uso na comunidade linguística e em termos de frequência. 


\subsubsection{Restrições}

Ainda que de forma não consciente, o falante domina os padrões morfológicos da sua língua materna (Rodrigues 2014; 2015). $\mathrm{Na}$ morfologia derivacional, os padrões morfológicos podem ser mais gerais e mais particulares.

Por exemplo, um padrão geral indica que é possível formar verbos a partir de nomes.

Assim, podem-se formular padrões gerais, como os que de seguida se elencam, e que relacionam um tipo de base com um tipo de produto:

- Nomes a partir de verbos

- Verbos a partir de nomes

- Nomes a partir de adjetivos

- Adjetivos a partir de nomes

Contudo, não existe nenhum padrão que permita gerar advérbios a partir de nomes, por exemplo, o que impede a formação de advérbios com base nestes ("gatamente, *velamente, *tabuamente).

Dentro de cada padrão existem subpadrões, que regulam as combinatórias possíveis entre tipos de bases e tipos de produtos, entre bases e afixos.

Por exemplo, um subpadrão indica que é possível formar adjetivos com base em nomes (cristal > cristalino, gás > gasoso, manha > manhoso), mas tais nomes não podem ser eles próprios bases de adjetivos:

(36) vermelho > vermelbidão $>$ *vermelhidoso

(37) tranquilo $>$ tranquilidade $>$ *tranquilidadino

As restrições localizadas nos subpadrões podem ser de vária ordem (Plag 2003: 59-68; Bauer 1983: 84-99; Lieber 2010: 64-65; Gaeta 2015), como veremos a seguir. 


\subsubsection{Restrições fonológicas}

As restrições fonológicas impedem que determinados afixos se juntem a bases que possuem determinadas caraterísticas fonológicas de modo a evitar dificuldades de interpretação da forma gerada. Por exemplo, o sufixo -iz-, que forma verbos a partir de nomes e de adjetivos, não se junta a bases cujo radical termina em vogal acentuada:

$$
\begin{aligned}
& \text { (38) } \text { café }>\text { *cafeizar } \\
& \text { rapé }>\text { *rapeizar } \\
& \text { rubi }>\text { *rubi(i)zar } \\
& \text { pá }>\text { *paizar } \\
& \text { afã }>\text { *afaizar }
\end{aligned}
$$

\subsubsection{Restrições semânticas}

A combinatória entre bases e afixos pode ser impedida por razões de caráter semântico. Algumas destas restrições são de natureza lógica. Por exemplo, não é possível anexar o prefixo des- a bases que denotem processos irreversíveis. Comparem-se *desmorrer; *desnascer; *desmatar com desaparecer, descompensar, descongelar.

Existem restrições semânticas que têm um caráter mais complexo ou menos óbvio. O falante opera com essas restrições implicitamente, sem que tenha noção do motivo ou mesmo da existência da restrição. Os verbos que são produzidos através dos sufixos -iz- e -ific- podem dar origem a nomes de ação. Contudo, o sufixo -ment- não se pode juntar a estes verbos, mas sim o sufixo -ção.

(39) urbanizar > urbanização /*urbanizamento solidificar >solidificação/*solidificamento 
Por sua vez, os verbos construídos com os sufixos -ec- e -escnão admitem o sufixo -ção para formarem nomes, mas já admitem o sufixo -ment-.

\section{(40) amarelecer $>$ amarelecimento/*amareleceção ruborescer $>$ ruborescimento/"ruboresceção}

O motivo que leva a esta restrição prende-se com a combinação semântica entre as duas séries de sufixos (Rodrigues 2008: 300-302). Os sufixos -iz- e -ific- geram verbos que designam ações efetuadas. Do mesmo modo, -ção indica a efetuação da ação. Os sufixos -ece -esc- geram verbos que designam o processamento do evento, assim como -ment-.

Estas restrições semânticas revelam-se sob a forma de restrições de caráter morfológico: o sufixo $\mathrm{X}$ não se combina com o sufixo $\mathrm{Y}$. Contudo, por detrás destas impossibilidades combinatórias entre os sufixos estão restrições semânticas.

\subsubsection{Restrições pragmáticas}

Restrições pragmáticas envolvem fatores não estruturais que passam, por exemplo, por afixos que estão na moda. Veja-se o uso intenso na atualidade de mega- (mega concerto, mega convívio, mega evento) e de super- (super proteico, super galático). O motivo que leva a que numa dada sincronia um afixo seja mais produtivo do que outro parece, por vezes, sair fora do domínio estrutural e explicar-se apenas com base em fatores sócio-culturais. Atente-se, por exemplo, no seguinte facto: o sufixo -inh-desempenha um papel central sob o ponto de vista pragmático na língua portuguesa (cf. cap. 5), seja na denominação (mãezinha), seja na interação (traga-me o leite quentinho.....; um cafezinho, por favor...). Assim 
não acontece com -it-, sufixo avaliativo que, no português europeu, goza das mesmas propriedades semântico-categoriais e das mesmas restrições combinatórias.

\subsubsection{Restrições morfológicas}

As restrições morfológicas fazem com que determinado formato morfológico da base impeça ou admita um processo derivacional ou um operador afixal. As restrições morfológicas podem assentar em restrições semânticas, etimológicas ou ainda argumentais. Assim, o motivo por que -ção se conjuga com verbos em -iz- e -ific-é de caráter semântico. Trata-se de restrições entre morfemas e, por isso, morfológicas, mas que são devidas a outro teor de restrições. $\mathrm{O}$ mesmo acontece em relação à restrição entre o sufixo -ão e verbos em -iz- e -ific-. Também se trata de uma restrição entre morfemas, mas a razão é etimológica. O sufixo -ão [- erudito] não se junta os sufixos -iz-e -ific- [+ eruditos].

Há, no entanto, restrições puramente morfológicas, ou seja, que se relacionam apenas com a morfologia dos constituintes e não têm uma motivação de outra ordem. Trata-se, por exemplo, da restrição que faz que o sufixo -ment- se agregue ao verbo na forma do tema do particípio e não na forma do tema do presente. Isto é visível quando a base é um verbo de tema em -e. Em nascimento observa-se que o tema é nasci-, ou seja, correspondente ao tema do particípio (nascido) e não ao tema do presente (nascemos). O sufixo -dor já seleciona o tema do presente (corredor) e não o do particípio (*corridor).

Outro exemplo de restrição morfológica é dado pela formação de advérbios em -mente. Este sufixo junta-se a bases adjetivais na forma feminina, no caso de o adjetivo ser variável em género (lindamente /"lindomente). 


\subsubsection{Restrições argumentais}

Os verbos inacusativos, como amadurecer, aparecer, chegar, crescer, envelhecer, existir, ruborescer, não formam nomes conversos/ não sufixados do tipo abraço, amparo, caça, salto, nem nomes em -aria, do tipo barbearia, gritaria. As restrições argumentais não se limitam à seleção do afixo ou do processo gerativo. Também atinge as dimensões semânticas. O sufixo -aria, quando se junta a verbos inergativos, não forma locativos, mas apenas nomes de ação (gritaria). Todavia, quando se junta a verbos transitivos, forma locativos (barbearia; branquearia) e nomes de ação (marchetaria, pescaria).

\subsubsection{Restrições etimológicas}

A língua portuguesa tem afixos e bases marcados como [+ eruditos], i.e, cuja configuração é próxima do formato [+ latino] ou [+ grego], e também morfemas [- eruditos], que não se aproximam desses formatos. Face a esta realidade, é natural que nela se façam sentir restrições assentes na natureza [ \pm erudita] de certos formantes. O sufixo -ão, [- erudito], que serve para formar nomes de agente e nomes de ação juntando-se a bases verbais (chorar > chorão, empurrar > empurrão), não se agrega a bases [+ eruditas], como se observa nos exemplos bibernar $>$ *hibernão, latinizar $>$ *latinizão, solidificar $>$ *solidificão.

\subsubsection{Restrições processuais: os bloqueios}

O bloqueio (Plank 1981; Rainer 1988; Bauer 1983: 87-88; Plag 2003: 63-68) costuma ser descrito como um impedimento em se formar um lexema quando no léxico já existe outro com o mesmo significado. Assim, a existência do lexema garfo bloque(ar)ia 
a forma *espetador. Se assim fosse, não existiriam sinónimos. Em português, o lexema ladrão não bloqueou os lexemas deverbais assaltante e roubão, enquanto em inglês a existência de thief, apontada tradicionalmente como motivo de bloqueio de stealer, não funcionou realmente como impedimento à sua formação, pois atualmente encontra-se registado o lexema stealer.

Este bloqueio de sinónimos deve ser objeto de reflexão, pois não é o facto de se construir um novo sinónimo que intervém de modo decisivo no bloqueio da nova forma. Investigação psicolinguística (Plank 1981; Rainer 1988) mostra que a frequência do lexema que tem a capacidade de bloquear o seu sinónimo tem um papel determinante nesse bloqueio. Assim, se o lexema existente tiver alta frequência de uso, está mais facilmente armazenado na memória e, logo, maior capacidade terá de bloquear o sinónimo. Isto é sobretudo visível na morfologia flexional. Uma forma como fiz bloqueia o seu sinónimo fazi quando se encontra, pela sua alta frequência, inscrita na memória. O que acontece na criança que produz fazi é que a forma fiz ainda não está armazenada na memória por não ter uso frequente pela mesma. Logo, fiz não bloqueia a forma regular fazi. No adulto, a forma fiz adquire maior acessibilidade lexical, pelo facto de, pelo seu uso frequente, se encontrar armazenada na memória. Logo, bloqueia a forma regular fazi.

Assim, não está em causa impedir a existência de sinónimos, até porque as línguas estão repletas deles. Está antes em causa haver uma preferência pela forma mais facilmente acessível.

Situação diversa é aquela que impede que afixos operadores de uma mesma regra de formação de palavras se anexem à mesma base. Por exemplo, no âmbito da regra de formação de nomes de ação a partir de verbos, operam afixos tais como -ção, -ment-, -dur-, -agem, -ão, -ari-. É possível anexar-ari(a) a gritar e assim obter-se gritaria. Mas não é possível anexar-se -ção (*gritação) ou -agem ("gritagem) ou -ment- ("gritamento). 
Este impedimento não se deve, no entanto, à necessidade de se evitar a construção de sinónimos. A partir de lavar construíram-se lavagem, lavadura, lavação, lava, lavadela. Não se trata de sinónimos perfeitos, como o não são os lexemas que numa língua mantêm entre si esse tipo de relação. Mas o que importa é constatar que não pode ser esse o motivo impeditivo de a mesma base sofrer sufixação vária dentro da mesma RFP.

Pelo exposto, as razões que levam à indisponibilidade entre gritar e alguns afixos deverão ser encontradas nas restrições estruturais que apresentámos acima (Rodrigues 2015).

Da mesma forma, o bloqueio de homónimos não deverá ser considerado como determinante: abridor 'instrumento para abrir garrafas' bloqueará o lexema *abridor 'porteiro'? Repare-se que existem em português muitos pares com semantismos diversos, como corredor 'espaço' e corredor 'aquele que corre' ou contador 'instrumento' e contador 'aquele que conta'. Existem mecanismos cotextuais de desambiguar os homónimos, pelo que não deve ser esse caráter a impedir a formação de lexemas. Muitas vezes, várias restrições se reúnem para impedir que se construa um determinado lexema. As restrições operam, pois, em simultâneo.

\subsubsection{Paradigmas}

Sabemos que o falante dispõe de padrões mentais, construídos inferencial e implicitamente através da análise da língua, que regulam a formação dos lexemas e a formação das formas de palavras. O paradigma flexional encerra o padrão utilizado para construir as várias formas do lexema. No caso dos verbos, a vogal temática tem um papel muito importante na indicação do paradigma, como se depreende se imaginarmos que desconhecemos a vogal temática de um verbo, de que possuímos apenas o radical ront-. A variação 
dessa forma depende da indicação do paradigma a que pertence. Este dado é importante, como se compreende através do contraste entre formas próximas, mas conjugacionalmente muito diferentes, como falir e falar ou remir e remar.

No caso da morfologia derivacional, os paradigmas organizam as relações entre as bases, os afixos e os produtos (Corbin 1987; Rio-Torto 1993; 1998). Os paradigmas não são meramente indicações formais. São indicações formais e também semânticas. Tradicionalmente, concebe-se que o falante pode construir dois tipos de paradigmas essenciais na morfologia derivacional (Rodrigues 2008: 42-45). Um paradigma encontra-se organizado por bases (Corbin 1987). Outro paradigma está organizado por afixos (Plag 1999). Um e outro são atravessados por carateres semânticos que uniformizam os paradigmas.

A linguística habituou-se a observar esses dois paradigmas isoladamente como se fossem rivais ou como se a existência de um impedisse a existência de outro. Contudo, é possível postular que ambos existem e que se intersecionam sem rivalidade. A organização mental assim o permite (Rodrigues 2008; 2012; 2015; 2016).

\subsubsection{Paradigmas organizados por bases}

Os paradigmas podem ser organizados em função das bases em jogo, como se observa nos três quadros seguintes.

\begin{tabular}{|l|l|}
\hline habilitação & 'ação de habilitar' \\
\hline desenvolvimento & 'ação de desenvolver' \\
\hline secagem & 'ação de secar' \\
\hline gritaria & 'ação de gritar' \\
\hline vingança & 'ação de vingar' \\
\hline
\end{tabular}

Quadro I. 6. Nomes de evento deverbais 


\begin{tabular}{|l|l|}
\hline secador & 'aquilo que seca' \\
\hline trituradora & 'aquilo que tritura' \\
\hline desmaquilhante & 'aquilo que desmaquilha' \\
\hline saltão & 'aquilo que salta' \\
\hline dobadoura & 'aquilo que doba' \\
\hline
\end{tabular}

Quadro I. 7. Nomes de agentes deverbais

\begin{tabular}{|l|l|}
\hline manhosice & 'qualidade do que é manhoso' \\
\hline tristeza & 'qualidade do que é triste' \\
\hline solidez & 'qualidade do que é sólido' \\
\hline musicalidade & 'qualidade do que é musical' \\
\hline libertinagem & 'qualidade do que é libertino' \\
\hline
\end{tabular}

Quadro I. 8. Nomes de qualidade deadjetivais

No Quadro I.6 encontramos nomes que têm base em verbos e que partilham a significação de 'evento de V'. No Quadro I.7 registam-se nomes que provêm de verbos e que designam 'aquilo que $V^{\prime}$.

Se tivermos uma base verbal como desratizar e se quisermos formar um nome de 'ação', seguimos o paradigma mostrado no Quadro I.8 e construímos desratização. Se com a mesma base quisermos formar um nome que designe 'aquilo que desratiza', formamos desratizante e desratizador.

Cada paradigma é assim constituído por um conjunto de bases possíveis, uma relação semântico-categorial entre bases e produtos e um conjunto de afixos e de processos derivacionais que podem operar nessa relação (Corbin 1987; Rio-Torto 1993). No conjunto das bases possíveis está determinada a categoria lexical da base. Por exemplo, no paradigma que permite formar desratização com base em desratizar, as bases têm que pertencer à categoria dos verbos e não podem pertencer a outra categoria: por exemplo, cadeira não pode funcionar como base deste paradigma. Para além desta restrição, há a considerar uma série de outras restrições (cf. cap. 
1: 1.5.3) que permitem ou impedem que um determinado verbo possa funcionar como base nesse paradigma e possa combinar-se com cada um dos operadores afixais.

Cada paradigma inclui a relação categorial e semântica entre bases e produtos. No quadro I.6 e no quadro I.7 as bases são verbos e os produtos são nomes. No entanto, o resultado semântico desses nomes é perfeitamente distinto, de tal modo que não incluiríamos desratizador no paradigma de habilitação. Da mesma maneira, no quadro I.10 os produtos são nomes, mas não significam 'evento de V', nem 'aquilo que V', nem se relacionam com uma base verbal. Logo, não se enquadram nos paradigmas representados nos quadros I.6 e I.7.

Designam-se por Regras de Formação de Palavras (RFPs) (Corbin 1993; Rio-Torto 1993; 1998) estes paradigmas (i) que se encontram organizados por bases com a mesma categoria lexical e (ii) que dão origem a produtos que partilham a mesma categoria lexical e o mesmo tipo de semantismo, através de um conjunto de afixos.

$R F P$ : relação entre um tipo léxico-semântico de base e um tipo léxico-semântico de produto através de um conjunto de afixos que operam essas relações.

As Regras de Formação de Palavras destacam o tipo de base e a relação desta com o produto. Nestas regras, os afixos são instrumentos ao serviço da construção de cada tipo de produto com base num tipo de derivante.

As Regras de Formação de Palavras, sendo formulações do linguista, pretendem descrever paradigmas de formação de palavras existentes na mente do falante. Não se trata de mero artifício do linguista, pois deverão ter uma relação com o modo como o falante opera mentalmente (com) os lexemas da sua língua. 


\subsubsection{Paradigmas organizados por afixos}

Há outra forma de o falante construir paradigmas da formação de palavras da sua língua (Plag 1999). Observemos os dados presentes no quadro seguinte:

\begin{tabular}{|l|l|}
\hline casacão & 'casaco grande' \\
\hline chorão & 'aquele que chora muito' \\
\hline bonitão & 'muito bonito' \\
\hline beliscão & 'beliscadura grande' \\
\hline carrão & 'carro de gama alta' \\
\hline
\end{tabular}

Quadro I. 9. Derivados em - ão

Todos os produtos lexicais deste quadro têm uma significação de 'aumento/ intensidade'. Esse semantismo é da responsabilidade do sufixo -ão. No entanto, estes lexemas não podem ser integrados num mesmo paradigma organizado por bases, como acontecera nos dados dos quadros I.6-8. Assim, carrão e casacão são nomes derivados de nomes. Bonitão é adjetivo derivado de adjetivo. Beliscão e chorão são nomes derivados de verbos.

Quanto à significação dos produtos, beliscão designa 'evento de V', sendo possível integrá-lo no paradigma em que foram colocados desratização, habilitação, desenvolvimento e secagem. Chorão designa 'aquele que V', pertencendo, pois, ao paradigma de secador, trituradora, desmaquilhante, saltão, dobadora e desratizador. Casacão, carrão e bonitão pertencem ao paradigma que permite formar avaliativos, neste caso aumentativos. Estes são lexemas que partilham com a base a mesma categoria lexical. Assim, se a base é um nome, o produto é também um nome; se a base é um adjetivo, o produto é também ele um adjetivo.

No quadro I.9 existem lexemas de três RFPs distintas. Contudo, todos têm em comum o semantismo de 'aumento/intensidade' de- 
vido ao sufixo -ão. Deve-se ao sufixo a homogeneidade semântica observável entre os vários produtos. $\mathrm{O}$ semantismo do sufixo pode servir, pois, de núcleo congregador dos paradigmas (Plag 1999).

\subsubsection{Interseção de paradigmas}

Do acima exposto advêm questões teórico-metodológicas que se prendem com a uniformidade semântica dos produtos, por um lado, e com a heterogeneidade categorial entre bases e derivados, por outro, que impede a inserção destes objetos no mesmo paradigma organizado por bases. Teoricamente há várias soluções para solucionar esta situação: (i) considerar que existem três sufixos homónimos -ão, cada um deles operando em sua RFP; (ii) considerar que se trata de um único sufixo - ão que se anexa a várias categorias lexicais; (iii) considerar que a organização mental da formação de palavras se faz em simultâneo segundo dois eixos principais: 1) a organização por afixos; 2) a organização por bases.

A primeira solução é empiricamente falível: os produtos em -ão partilham o semantismo de 'aumento/intensidade', independentemente do tipo de base a que se junta o sufixo, ou seja, independentemente da RFP em que o produto foi formado. Significa isto que multiplicar em homónimos um -ão que é uniforme é demasiado artificial.

A segunda solução, de dar apenas importância ao semantismo do sufixo e deixar de lado a partilha quer categorial, quer semântica entre as bases, esquece algo que empiricamente é saliente: os paradigmas das RFPs.

A terceira solução é a mais adequada quer empírica, quer teoricamente, desde que tenhamos em consideração que a mente do falante tem capacidade de estruturar funções em várias dimensões e não apenas numa (Rodrigues 2015; 2016). 
Se fizermos um exercício de organização de grupos com os lexemas velhice, amabilidade, robustez, livraria, calmaria, refinaria, passarada, barbearia, mulherio, moagem, é certamente possível formar grupos distintos de acordo com dois eixos.

Um eixo baseia-se na relação entre o tipo de base e o tipo de produto. Neste eixo são tidos em conta os seguintes aspetos, mesmo que implicitamente: categoria da base, categoria do produto, semantismo do produto em relação com a base. Obtemos assim os seguintes grupos:

(i) velbice, amabilidade, robustez, calmaria

(ii) livraria, passarada, mulherio

(iii) refinaria, moagem, barbearia

No primeiro grupo, há nomes que designam 'qualidade', formados a partir de adjetivos. No segundo grupo estão nomes que designam 'coletivo', formados a partir de nomes. No terceiro grupo estão nomes que designam a 'atividade' e 'local onde se faz a atividade', formados a partir de verbos.

Um segundo eixo leva-nos a formar outro grupo: calmaria, livraria, refinaria, barbearia.

Este grupo tem como ponto de suporte o sufixo -ari-, partilhado pelos lexemas. Esta partilha não é só formal, ou seja, não é só a forma em -ari-aquilo que une estes lexemas. Em todos eles existe um semantismo de 'quantidade' moldado de acordo com as bases a que se junta o sufixo. Em livraria o semantismo de 'quantidade' é literal, na medida em que uma livraria tem necessariamente uma quantidade apreciável de livros. Em refinaria, barbearia 'quantidade' revela-se na multiplicação do designado pelas bases, que desemboca numa 'atividade' e no 'local onde se faz essa atividade'.

A mente do falante tem capacidade para organizar diferentes paradigmas, baseados em parâmetros distintos. A descrição dos dois 
tipos de paradigmas e não de apenas um por parte do linguista revela-se mais de acordo com os dados empíricos (Rodrigues 2008).

\subsubsection{Formação 'cruzada' (ing. cross-formation)}

Existem lexemas que se relacionam com outros lexemas, mas para os quais não é possível encontrar uma relação derivacional direcionalmente marcada (Plag 2003: 182-187).

Se tivermos em conta o nome desratização e o verbo desratizar, facilmente observamos que os morfemas do verbo estão contidos no nome (des+rat $+i z+a)$. Em termos semânticos, também o semantismo do nome 'ação de desratizar' está dependente do semantismo do verbo. Por conseguinte, quer os dados formais, quer os semânticos mostram que a direção derivacional entre o nome e o verbo é $\mathrm{V}>\mathrm{N}$.

O problema surge em situações do tipo de elegante e elegância. Comparem-se estes com desmaquilhante, solvente, solvência, radiância. Em desmaquilhante, solvente, solvência, radiância podemos estabelecer relação com desmaquilhar, solver, radiar. Mas elegante teria relação morfológica com que base?

O mesmo ocorre com elegância, que se relaciona paradigmaticamente com solvência e radiância. Mas radiância correlaciona-se com radiar, solvência com solver.

Todavia, elegância e elegante não possuem uma base de que derivem. Uma solução consiste em recorrer à história destes lexemas. Neste caso, o problema fica resolvido, pois elegante e elegância provêm das formas latinas ELEGANTE- e ELEGANTIA-. Maior problema surge quando os lexemas se encontram relacionados entre si, mas não são empréstimos de outra língua. Encontram-se nesta situação pesporrência/pesporrente. Foram estes lexemas formados em português? Com que matéria-prima? 
Estes exemplos enquadram-se na chamada formação cruzada (cross-formation (Becker 1993: 8-18)). Trata-se de uma formação paradigmática de lexemas para os quais não existe a suposta base. Os produtos gerados através de sufixação encontram-se correlacionados entre si, partilhando a mesma base hipotética. A formação destes lexemas faz-se ativando dois paradigmas genolexicais, neste caso o de formação de nomes em -nci- e o de formação de nomes em -nt-. A relação entre pesporrência e pesporrente faz-se bidirecionalmente. Não é possível considerar um deles como base do outro, visto não haver direcionalidade morfológica entre eles. Ocorre uma comutação entre os afixos. São produzidos através deste processo paradigmático barbiturismo/barbitúrico, hedonismo/bedonista, mercearia e merceeiro, por exemplo.

\subsection{Processos de formação}

Os processos de formação de palavras correspondem a mecanismos formais de criação de lexemas (Mel'čuk 2000; Rio-Torto 1998c). Os processos podem ser de vária ordem:

i) junção de afixo a uma base lexical;

ii) junção de pelo menos duas bases lexicais;

iii) mutação da categoria da base lexical sem junção de constituinte derivacional;

iv) alterações na estrutura fonológica/prosódica da base.

\subsubsection{Afixação}

A afixação designa a formação de palavras através da junção de um afixo a uma base. De acordo com a posição do afixo 
relativamente à base lexical (cf. cap. 1: 1.2.), estamos perante prefixação, sufixação, circunfixação e infixação. A interfixação designa a inclusão de um elemento sem semantismo no meio da base (cf. cap. 1: 1.6.1.4.).

Analisam-se de seguida as principais caraterísticas de cada um dos processos de afixação (Hall 2000; Spencer 2015).

\subsubsection{Prefixação}

A prefixação ocorre quando o afixo se junta à esquerda da base. É o caso de re+tomar, anti+coagulante, en+tort(ar), etc.

Ao contrário dos sufixos, os prefixos não alteram a acentuação da palavra base, se mantiverem no produto a mesma categoria lexical da base: amor > desamor. Já num produto prefixado como entortar, gerado a partir do adjetivo torto, o acento é alterado, de modo a conciliar-se com o padrão prosódico da categoria (verbo) resultante.

A anexação de um elemento à direita da base requer o reajustamento prosódico do formato do produto de maneira a que este se configure com o padrão geral de acentuação. Nas palavras sufixadas, a posição do acento no produto é muitas vezes diferente da da base: casa, caseiro, casota, cavalo /cavalinho, papel, papelão).

Outra caraterística muitas vezes apontada relativamente ao prefixo é a de que este não altera a categoria lexical da palavra base. Contudo, esta caraterística não se verifica em alguns prefixos: $a_{-}, e n-$, es-, que formam verbos a partir de adjetivos e de nomes, promovem alteração da categoria da base (torto > entortar; terra > aterrar). Por sua vez, também há sufixos que não alteram categorialmente o produto em relação à base: assim acontece com mulher $>$ mulherio, pássaro > passarada, por exemplo, assim como os avaliativos (bonito > bonitão; gato > gatinho; saltar > saltitar). 
Comparando ainda prefixos e sufixos, os primeiros apresentam menos constrições de anexação às bases do que os segundos. Por exemplo, re-parece ser agregável a qualquer base verbal, desde que esta designe um evento 'reversível' (reler, reprogramar, reabrir; mas "remorrer, *rematar no sentido de 'tornar a matar'). No que diz respeito aos sufixos, o mesmo se verifica apenas em relação aos avaliativos (-inh-parece agregar-se a qualquer base nominal e adjetival).

Os prefixos não apresentam uma seletividade categorial tão notória como os sufixos: ante- agrega-se a nomes (antessala), a adjetivos (anteverde), a verbos (antepor). Embora o mesmo se verifique em alguns sufixos (e.g. - ari(a) seleciona verbos (gritaria), nomes (livraria) e adjetivos (calmaria)), não parece ser uma caraterística tão marcada quanto nos prefixos.

Uma das diferenças mais sensíveis entre sufixos e prefixos é a seguinte: com exclusão da prefixação heterocategorial, os prefixos não modificam as classes temáticas das bases. Assim, voto $>$ pré-voto; possivel > impossivel; caro >supercaro; amizade > inimizade. $\mathrm{O}$ mesmo não se verifica nos sufixos (leve > leveza, pedir > pedinchar).

Os prefixos prototipicamente não alteram as categorias morfossintáticas das bases, mantendo o mesmo género e possibilidade de flexão em número (o feliz, os felizes; o infeliz, os infelizes). Também não alteram categorias morfossemânticas (honra > desonra mantém-se incontável). Em 1.6.1.4 apresentam-se mais dados acerca da composição e da prefixação.

\subsubsection{Sufixação}

A sufixação é, nas línguas românicas, a grande responsável pela recategorização de produtos lexicais. Para além da mudança de categoria lexical, a sufixação é também responsável por outro tipo de mudança do produto em relação à base: uma mudança de 
natureza semântica, que inscreve o denotado pelo derivado numa classe ontológico-referencial diferente da da base.

Atentemos nos seguintes exemplos:

\begin{tabular}{|l|l|}
\hline Bases e nomes sufixados & Bases e nomes/adjetivos prefixados \\
\hline casa $>$ casario & amor $>$ desamor \\
folha $>$ folhagem & felicidade $>$ infelicidade \\
livro $>$ livraria & sala $>$ antessala \\
pena $>$ penugem & normal $>$ anormal \\
punhal $>$ punhalada & ligar $>$ religar \\
\hline
\end{tabular}

Quadro I.10. Bases e produtos sufixados e prefixados

Nos produtos sufixados do Quadro I.10, a categoria lexical da base permanece igual no produto. $\mathrm{O}$ mesmo acontece nos exemplos prefixados. No entanto, a categoria semântica da base não se mantém nos nomes sufixados, mas mantém-se em grande parte dos derivados prefixados. Casario, penugem, folhagem designam entidades que não pertencem às mesmas instâncias de casa, pena e folha. Estas designam unidades singulares; as primeiras designam unidades coletivas. Punhal designa entidade concreta; punbalada designa evento. Livro designa entidade concreta singular e livraria designa um local e um conjunto.

Nos produtos prefixados, desamor, infelicidade designam o mesmo tipo de instâncias denotadas por amor e felicidade. O mesmo acontece entre sala e antessala, designando ambos locais, assim como entre normal e anormal, que designam atributos, ou entre ligar e religar, que designam eventos.

Uma vez mais, também na sufixação é possível a manutenção da categoria semântica no par base-produto, como se observa nos avaliativos. Contudo, ela é dominante na prefixação. Na sufixação não ocorre repetição do mesmo operador: *punhaladada, *contabilizizar. A exceção reside, de novo, em alguns avaliativos (cf. cap. 5).

Os sufixos são responsáveis pelos seguintes tipos de produtos: 


\begin{tabular}{|l|l|l|}
\hline \multicolumn{1}{|c|}{ nominalização } & \multicolumn{1}{c|}{ adjetivalização } & \multicolumn{1}{c|}{ verbalização } \\
\hline (i). deverbal & (i). deverbal & (i). denominal \\
(avaliar $>$ avaliação); & (amar $>$ amável); & (guerra $>$ guerrear $) ;$ \\
(ii). deadjetival & (ii). denominal & (ii). deadjetival \\
(triste $>$ tristeza) $;$ & (seda $>$ sedoso); & (global $>$ globalizar); \\
(iii). denominal & (iii). avaliativa & (iii). avaliativa \\
(cristal $>$ cristaleira); & (isocategorial) & (isocategorial) \\
(iv). avaliativa & (verde $>$ verdinho) & (pedir $>$ pedinchar) $)$ \\
(isocategorial) & & \\
$($ bicho $>$ bichinho $)$ & & \\
\hline
\end{tabular}

Quadro I.11. Padrões de produtos formados por sufixação

Alguns sufixos têm a capacidade de introduzir nos seus produtos estrutura argumental. Isto acontece com os sufixos verbalizadores, mas também com alguns nominalizadores, como se observa nos derivados em -ção, -ment-, etc. Outros sufixos deverbalizadores nominais, como - ão, não apresentam essa capacidade.

\subsubsection{Circunfixação}

O termo circunfixação (Mel'čuk 1982: 84; Mel'čuk 2000: 528) substitui, porque clarifica, o de parassíntese. O termo parassíntese é tradicionalmente utilizado para referir dois fenómenos derivacionais distintos:

a) a formação de palavras através de um afixo descontínuo que se anexa à esquerda e à direita da base em simultâneo (entontecer);

b) a existência de uma unidade lexical constituída por um prefixo e um sufixo (infelizmente).

Em a), estamos perante um único processo de formação de palavras. O elemento da esquerda não se junta àquela base sem o elemento da direita (*entontar), nem o elemento da direita se junta à mesma base sem o elemento da esquerda (*tontecer). Significa, 
pois, que para a formação de entontecer concorreram em simultâneo duas partes de um constituinte descontínuo. Estamos perante um processo de circunfixação: o afixo circunda a base (en-velh-ec(er) vs. *en-velhar; *velhecer).

No caso b), não se trata de um só processo de formação de palavras. O prefixo in-agrega-se a felizmente. O sufixo -ment(e) agrega-se a infeliz. Ou, de outra forma possível, o sufixo -ment(e) agrega-se a feliz, o prefixo in-agrega-se a felizmente. Ou seja, existem as palavras constituídas somente pelo afixo da esquerda e pelo afixo da direita. Para que exista o lexema infelizmente, não é necessário que à base feliz se juntem obrigatoriamente e em simultâneo ine -ment(e). Em b) não há circunfixação, mas sucessivas afixações (feliz > infeliz > infelizmente; feliz > felizmente > infelizmente).

A circunfixação, em português, ocorre apenas na formação de verbos denominais e deadjetivais (cf. cap. 4: 4.3.3.4.). É necessário um esclarecimento em relação a este processo.

Observem-se os verbos: envelhecer, entortar, divinizar, falar. Apenas envelhecer exemplifica a circunfixação. O verbo entortar tem como base o adjetivo torto, ao qual se junta o prefixo en-. É este prefixo que é responsável pela recategorização do adjetivo em verbo. Não é a VT -a (entortar) que é responsável pela derivação verbal, nem o morfema $-r$ do infinitivo. $O$ facto de o infinitivo ser a forma citacional nas línguas românicas não lhe confere estatuto lexical derivacional. Quanto à VT, se fosse responsabilidade desta a formatação do lexema como verbo, as formas gramaticais que a não apresentam estariam desprovidas de categoria verbal (canto, cante, etc.).

Verifique-se ainda que tanto a VT, como qualquer morfema flexional de MTA, ocorre com qualquer verbo, seja derivado ou não derivado. Assim, nos verbos acima listados, falar apresenta a mesma VT de entortar, embora seja não derivado. Mais: em verbos derivados por sufixação, como divinizar, ocorre a mesma VT ao 
lado de um sufixo responsável pela derivação (-iz-). Destas observações se conclui que:

1. a VT não é responsável pela derivação. Se assim fosse, não se explicaria a sua presença ao lado de sufixos derivacionais, como em divin+iz+a(r);

2. se a VT fosse responsável pela derivação, não poderia ocorrer em verbos não derivados, como amar, correr, ouvir.

Assim, formas como entortar não são produtos de circunfixação. Não se trata da anexação de um constituinte descontínuo (*en-...-ar) a uma base. Trata-se da anexação de um prefixo (en-) a uma base correspondente ao radical do adjetivo (tort-) e da sequente colocação dos morfemas de flexão inerentes à categorial lexical entretanto formatada.

\subsubsection{Interfixação e infixação}

Os interfixos (Haspelmath 2002: 86; Bauer 2004; Mel'čuk 2000: 528) e os infixos (Plag 2003: 11; Haspelmath 2002: 19; Bauer 2004; Mel'čuk 2000: 528; Moravcsik 2000) são constituintes que ocupam uma posição medial dentro do produto. A distinção entre interfixos e infixos faz-se tendo em conta o caráter semanticamente vazio do primeiro, por oposição ao caráter semântico do segundo. O interfixo não apresenta carga semântica. A sua presença deve-se a necessidades mórficas. Pelo contrário, o infixo acarreta um contributo semântico para o produto.

Os interfixos correspondem aos constituintes morfológicos que se seguem à base e precedem outra base, no caso de composição (rabirruivo). No caso da afixação, os interfixos localizam-se entre a base e o afixo derivacional (tecelão) Os interfixos têm um caráter meramente morfológico, isto é, detêm um papel funcional, mas não semântico, na formação do novo lexema. 
Tradicionalmente, os interfixos são designados por vogais/consoantes de ligação ou epentéticas (fumívoro, chaleira) e os infixos são designados por sufixos, no caso dos avaliativos (facalbão, lambarão).

As funções a que se prestam os interfixos, de caráter morfómico (Aronoff 1994), são sobretudo de ordem fonológica:

1) evitam o aparecimento de hiatos (casarão; chaleira; comilão; tecelão; tecelagem);

2) preservam a identidade morfológica da base (tecelão vs. *teção; lãzinha vs. *lãinha; corpanzil vs *corpanil ou *corpãoil).

Os infixos possuem funcionalidade semântica. Em português, ocorrem na formação de avaliativos. A infixação distingue-se da situação em que há recursividade sufixal. Neste último caso, não se trata de adjunção de um infixo, mas de um sufixo que se sucede a outro em fases diferentes da formação de unidades lexicais diferentes. Por exemplo, burriquito tem origem no derivado burric(o). A forma burrico é autónoma em relação a burriquito. Já em zangarrão existe um verdadeiro infixo (-arr-) que precede o sufixo -ão. Não está disponível a forma *zangarro, a que se pudesse unir o sufixo - ão. Por isso se considera que o processo não é sequencial, ou seja, não se trata de recursividade derivacional. Trata-se de, em simultâneo, se colocar um infixo entre a base e o sufixo. Repare-se que não é possível considerarmos uma só unidade afixal -arrão (cf. cap. 5). As unidades -arr-e -ão existem autonomamente (bocarra) e -ão combina-se com outros infixos (benzilhão, sabichão).

\subsubsection{Composição}

Composição designa o processo de formação de palavras em que se juntam dois ou mais constituintes que podem funcionar como 
bases (Fabb 1998): girassol, papa-formigas. Esta é uma caraterística que separa a composição da afixação, dado que os afixos não se podem combinar entre si como se fossem eles mesmos bases. (antirrugas vs. *antiar, *reanti, *desantiar, *anteanti).

Ao contrário do sintagma, o composto é morfologicamente sólido, no sentido em que pode integrar o léxico de modo estável (Olsen 2000: 898; 2015).

As caraterísticas do composto habitualmente apontadas são: as formas são dominadas por um acento primário comum, que em português corresponde ao da sílaba acentuada da base mais à direita (guarda-chuva); as formas não podem ser separados por outro constituinte [*girarápidosol); o resultado semântico não se subsume na simples adição dos semantismos das bases (e.g. aguardente não é uma água que arde, ou qualquer água que arde).

A distinção entre composição e afixação nem sempre é simples. A maior dificuldade reside na classificação de um elemento como afixo ou como base. Esta questão coloca-se relativamente a duas entidades: os prefixos e os constituintes dos compostos neoclássicos.

O problema dos prefixos reside no seguinte: a maioria dos prefixos das línguas românicas corresponde historicamente a preposições, ou seja, a unidades com autonomia formal, mas com funcionalidade semântica restrita. Prefixos como en- $a$-, es- são exemplos dessa mutação de preposições em elementos prefixais (cf. cap. 4). Em gramáticas históricas (vg. Diez 1874; Meyer-Lübke 1895), os prefixos são tratados no capítulo da composição.

Alguns autores falam de pseudo-afixos ou afixoides (Herculano de Carvalho 1984: 547-555). Não será necessário utilizar esta designação se tivermos em conta que há sempre entidades menos centrais do que outras. Em todo o caso, estes constituintes situam-se numa fase de transição entre o estatuto de bases e o de afixos. 
São as seguintes as caraterísticas destes constituintes (ten Hacken 2000: 355):

a) produtividade crescente;

b) diminuição da especificidade semântica;

c) relação etimológica e formal com uma base.

Sob o ponto de vista paradigmático, os afixoides estão em distribuição complementar com afixos. Sintagmaticamente, os afixoides têm distribuição diferente das bases.

Em relação ao português, alguns prefixos encontram-se já numa fase perfeitamente consolidada dessa transição. Encontram-se nessa situação a-, en-, es-, por exemplo. Já os exemplos de ante-, pós-, sobre-, sub- mostram uma fase de transição.

Para se comprovar que estes constituintes possuem o estatuto de prefixos em lexemas como anteaurora, pós-moderno, submundo, recorremos aos critérios antes apontados (secção 1.1.4.), segundo os quais o afixo se distingue de uma preposição pelas possibilidades sintagmáticas que a segunda acarreta.

a) o afixo não admite alteração na sua posição em relação à base (a aurora ante a qual me vi era belíssima/vi-me ante uma aurora belíssima vs. a anteaurora era belíssima/*a aurora ante era belíssima.).

b) o afixo não admite inclusão de outros constituintes entre si e a base, nomeadamente de determinantes ou quantificadores (o período pós-moderno vs. *o período pós de moderno).

Para além disso, o prefixo apresenta diferenças semânticas em relação à preposição:

c) o resultado semântico do produto não é linear relativamente ao do sintagma. Assim, o submundo não é um mundo sob o mundo; os pré-rafaelitas não são situados cronologicamente 
antes de Rafael; a anteaurora não está antes da aurora, mas nesta incluída.

Não nos parece bom critério considerar que estes elementos são bases, ou seja, operadores de composição e não de prefixação, pelo simples facto de apresentarem acento prosódico. Em primeiro lugar, trata-se de um acento secundário (Pereira 2000). Em segundo lugar, nada impede que um afixo possua acento. Vários sufixos (-íssim-, -ção) alteram a acentuação da palavra. Recorde-se que os prefixos não alteram a acentuação da base, a não ser que se trate de prefixação heterocategorial: pré-rafaelita apresenta acento primário em $/ l i /$.

As bases preservam autonomia semântica. Há prefixos que têm autonomia fonológica, mas não têm autonomia semântica, nem lexical. Por isso não funcionam como bases.

Estes traços que pretendem caraterizar ante-, sob-, pré-, etc. como elementos de prefixação e não de composição podem aparentemente ser usados do mesmo modo para os constituintes dos compostos neoclássicos. Contudo, em relação aos constituintes dos compostos neoclássicos, o problema coloca-se ao contrário. Estamos perante unidades que contêm formatação semântica referencial, mas que não apresentam autonomia formal. Ou seja, não ocorrem como palavras. A questão que se coloca é a seguinte: elementos como geo-, bio-, -eletro-, são prefixos ou são bases?

Os constituintes dos compostos neoclássicos apresentam caraterísticas diferentes das dos prefixos:

(i) carga semântica autónoma, referencial;

(ii) possibilidade de alternar posição (eletromagnético; hidro-elétrico; antropólogo vs. filantropo. vs *aurora-ante) (Scalise 1984);

(iii) possibilidade de ocorrerem combinados entre si (geologia, bidrófobo), enquanto os prefixos não podem combinar-se 
entre si para formarem um lexema (*antessub, *antipró, *contrassobre);

(iv) ocorrem em lexemas cujas bases só por eles é preenchida: em caseína, caseoso, caseificar, elétrico, os derivados contêm uma base não autónoma a que se junta um sufixo. Trata-se de lexemas para os quais não é possível apontar um correspondente em latim.

O facto de muitos dos constituintes dos compostos neoclássicos não existirem como bases autónomas não interfere no seu caráter lexical de base. Muitos são os processos afixais cujas bases são não autónomas.

O problema de delimitação da natureza dos constituintes verifica-se também em relação aos advérbios em -ment(e), devido à mudança ocorrida no caráter deste constituinte: -mente correspondia ao nome mens, -entis (cf. cap. 6). No entanto, no português atual, não é possível considerar que os produtos em -mente correspondam ao adjetivo no feminino mais o nome (Detges 2015). Para além de -mente ter perdido a carga semântica que continha em latim, ou que contém o nome mente, bem como a identidade com esse nome, os produtos em -mente são advérbios, enquanto mente é um nome. O mesmo acontece em inglês. Por exemplo, adjetivos como helpless, hopeless, integram o elemento -less que semanticamente não corresponde ao advérbio less. Não podemos parafrasear hopeless por less hope. (Plag 2003: 72-73).

Observaremos em seguida diferentes tipos de compostos.

Um composto é constituído pelo menos por duas bases. Como já vimos, essas bases são autónomas semanticamente e podem ser formalmente não autonómas. Uma das bases pode funcionar como núcleo do composto (Bauer 1983: 28-31; Matthews 1974: 82-101). O núcleo é o constituinte que determina a categoria lexical do produto, bem como a sua categoria semântica. Assim, uma 
andorinha-dos-beirais é um tipo de andorinha. O semantismo do produto funciona como um hipónimo do núcleo. A categoria lexical é a de nome, correspondente à categoria do núcleo (andorinha). Este tipo de composto é designado tradicionalmente por composto endocêntrico (Haspelmath 2002: 87; Matthews 1974: 90-92).

Os compostos exocêntricos, ou, na terminologia sânscrita, bahuvrihi (Bauer 1983:30), são aqueles em que nenhuma das bases funciona como núcleo semântico (Matthews 1974: 90-92; Haspelmath 2002: 88). Por exemplo: um rabirruivo não é um tipo de rabo, é uma ave. É um hipónimo de um referente não designado no composto, não é hipónimo do núcleo. A exocentricidade é semântica. Na realidade, o composto tem um núcleo interno: a categoria lexical é determinada pelo Nome (Plag 2003:146).

Noutros compostos os constituintes mantêm uma relação de copulatividade. Estes podem ser apositivos (autor-cantor) e coordenativos ou dvandva (Bauer 1983:30), na terminologia sânscrita, (austro-búngaro).

Um composto pode encerrar uma relação entre os constituintes de tipo núcleo/modificador (carro elétrico, estrela polar), argumento/ predicador (guarda-chuva, quebra-cabeças), aposição (autor-cantor, tradutor intérprete). Por este motivo, a composição é por alguns autores (Bauer 1988: 100-104; Lees 1960; Nevi 1978) encarada como do domínio da sintaxe. Contudo, o comportamento dos compostos tem mais relações com o léxico devido:

(i) à impossibilidade de se introduzir um constituinte estranho entre os constituintes do composto, ao contrário do que acontece num sintagma (coruja-do-mato vs. *coruja castanha do mato);

(ii) ao facto de o semantismo do composto não resultar da adição dos semantismos das partes (girassol designa uma planta e não qualquer objeto que gira ao sol); 
(iii) ao comportamento diferenciado da flexão: em compostos como guarda-chuva, apenas o segundo elemento recebe marca de flexão (os guarda-chuvas), ao contrário do que aconteceria numa frase: os guardas da prisão.

\subsubsection{Conversão}

Existem mecanismos de formação de novas unidades lexicais que não utilizam a junção de elementos, nomeadamente de operadores afixais a uma base (Bauer 2005; Kastovsky 2005, Don \& Trommelen \& Zonneveld 2000). Com efeito, a morfologia derivacional opera com alterações categoriais no léxico sem que haja vestígio formal direto dessa alteração, ou sem que haja um morfema responsável por essa mudança. A gramática tradicional serve-se das seguintes designações para esse mecanismo: derivação 'regressiva' e derivação 'imediata', integrando-se ambas naquilo que é designado por derivação 'imprópria' (Nunes [1919] 1989: 358-361). A derivação 'regressiva' é a designação utilizada para referir produtos nominais que têm base num verbo, como passeio de passear, boquejo de boquejar, grito de gritar. A derivação 'imediata' é a designação da gramática tradicional para os produtos verbais denominais como açucarar de açúcar, ancorar de âncora, olear de óleo. Estas designações são, no entanto, desadequadas, na medida em que apontam para mecanismos derivacionais que não estão na origem destes produtos (Rodrigues 2001: 34-37, Rodrigues 2002 e 2004b).

Como não existe nenhum morfema responsável pela conversão, ou seja, pela construção de um derivado a partir de uma base sem recurso à afixação ou à adição de bases (Anderson 1992: 21-22; Rodrigues 2001), quer isto dizer que a conversão não é um processo de formação de palavras ou que não é um processo morfológico de formação de palavras (Valera 2015)? 
Em português, é possível que se transmute em nome qualquer sintagma verbal, na frase, desde que coloquemos antes da forma do infinitivo do verbo um determinante, como exemplificado em (41).

(41) O ler muitos livros é sinal de cultura.

A formação dos nomes conversos rogo e voo e dos verbos conversos açucarar e relvar não se faz na sintaxe, como acontece com (41). Nestes produtos trata-se, de facto, de um verdadeiro mecanismo de formação de palavras.

Os argumentos a favor desta posição são os seguintes:

1) para se tratar de um fenómeno sintático, os derivados limitar-se-iam a sofrer uma mutação meramente cotextual. É isto que ocorre com o ler, o escrever, o olhar. A mudança é visível apenas pelas combinatórias cotextuais (ocorrência de determinante à esquerda do nome; ausência de flexão em modo-tempo-aspeto). Mas a flexão em número-pessoa mantém-se possível:

(42) O leres muitos livros dá-te mais cultura.

(43) O escrevermos a carta não nos desculpa da má ação.

Ora, os conversos rogo e voo não apresentam capacidade de manterem flexão típica de verbo, porque, na verdade, a mudança para nome está inscrita no léxico e não na sintaxe (Rodrigues 2013).

2) Poder-se-ia alegar que a mudança se dá na sintaxe e que, como tal, estamos perante um radical que é atualizado na sintaxe como nome, se lhe for agregado um índice temático nominal, ou como verbo, se lhe for anexado uma vogal temática verbal. Todavia, a inserção do constituinte temático, seja do verbo, seja do nome, não é feita a nível sintático, mas a nível lexical. Se ela tivesse lugar na sintaxe, seria possível converter qualquer verbo em nome e 
qualquer nome em verbo. Repare-se que a utilização do infinitivo como nominal é possível para qualquer verbo. Mas tal não se verifica nos derivados conversos. Existem restrições que impedem que determinados verbos sejam convertidos em nome. Essas restrições não são aleatórias. Estão antes relacionadas com parâmetros estruturais morfológicos e léxico-conceptuais-argumentais bem definidos (Rodrigues 2004; 2009).

3) Se se tratasse de uma mutação na sintaxe e não no léxico, o semantismo dos conversos seria previsível e linear em relação ao semantismo da base. Por exemplo, em (41), o ler ... é sinal de cultura, ler significa apenas 'ação de ler'. Ora, os conversos têm uma multiplicidade de semantismos, não se limitando a designar 'a ação de' (Rodrigues 2001). Em rogo, por exemplo, temos o semantismo de 'prece'; em remendo o semantismo de 'pedaço de tecido que se cose a outro'; em caça 'conjunto dos animais caçados', para além da designação de evento. Respiro designa 'orifício que deixa sair e entrar o ar'.

Ora, nenhum destes significados pode ocorrer nas mutações em sintaxe:

(44) a. *O respirar (d)o forno é muito apertado. vs. O respiro do forno é muito apertado.

b. *O rogar (d)a menina tinha erros. vs. O rogo da menina tinha erros.

c. *O remendar (d)a saia é branco. vs. O remendo da saia é branco.

A conversão é, pois, um processo não sintático, mas que dá origem a novos lexemas. Trata-se de um processo morfológico com consequências notórias ao nível morfológico. A conversão do radical verbal em nominal acarreta alterações a nível da formatação formal, 
o mesmo acontecendo quando o radical nominal ou adjetival se converte em verbal. Desde logo, o tipo de constituinte temático que se anexa ao radical é diferente consoante a categoria lexical do radical. Os morfemas de flexão vão ser necessariamente também diferentes. Isto significa que a morfologia opera com morfemas ou com processos que dão azo a alterações formais flexionais e estas só podem ocorrer se tiver havido alterações categoriais e subcategoriais sob o domínio daquela categoria lexical.

Acresce que as alterações operadas são semanticamente idiossincráticas e obedecem a restrições: nem todo o verbo dá origem a um nome, nem todo o nome dá origem a um verbo. Por último, as mudanças ao nível das categorias e sucategoriais indiciadas morfologicamente estão dependentes de mudanças na categoria lexical. O facto de a ocorrência em sintaxe do infinitivo como nominal admitir a flexão em número-pessoa mostra que a alteração categorial não se deu no léxico, ao contrário do que acontece na conversão.

\subsubsection{Verbos conversos}

O que está na origem de verbos como açucarar é a mutação da base nominal em base verbal. A hipótese de o responsável por esta mutação ser a terminação -ar não é adequada, uma vez que os constituintes flexionais não têm poderes categoriais (cf. cap. 4: 4.3.1.1. e 4.3.3.1.). A intervenção da marca do infinitivo na formação de verbos é nula. Mais: não é esta marca que dá ao lexema a categoria de verbo. Se assim fosse, uma forma como açucarei não pertenceria à categoria dos verbos, porque não tem a marca do infinitivo. O mesmo se pode dizer em relação à VT. A VT verbal ocorre em qualquer verbo, independentemente de ser derivado ou não, ou de ter um sufixo responsável pela sua formação. Para além do mais, há formas gramaticais em que não 
ocorre a VT e não é a presença/ausência desta que determina a categoria de verbo ou não verbo.

Nestes casos, em que não ocorre nenhum afixo responsável pela recategorização da base, considera-se que o radical da base sofreu essa recategorização no léxico. Assim: açúcar $\mathrm{N}>$ açúcar $\mathrm{V}$. Após esta recategorização, as formas de flexão podem anexar-se à base com a nova categoria.

\subsubsection{Nomes deverbais conversos}

Outro tipo de formação que não se socorre de afixação é a designada pela gramática tradicional por 'derivação regressiva'. Esta designação é ainda mais equívoca do que a de 'derivação imediata'. 'Derivação regressiva' aponta para um mecanismo de formação que na verdade não se deteta nestes produtos.

'Derivação regressiva' refere um mecanismo em que o produto resultaria da operação de supressão de constituintes à base. Ou seja, a gramática tradicional encara que, para se formar abraço a partir de abraçar, se tomou a forma do infinitivo à qual se retira a marca do infinitivo mais a VT. Restando o radical, iria depois colocar-se o índice temático do nome, segundo um esquema do tipo abraçar $>$ abraç > abraço. O produto resultante, na forma citacional, é mais curto do que a base, também na forma citacional. Daqui advém a noção de 'derivação regressiva'.

Depois de (i) termos alertado para o estatuto não fixo e não derivacional tanto do morfema do infinitivo como da VT e de (ii) termos entendido que na nossa mente o léxico se encontra organizado por paradigmas com formas gramaticais de cada lexema que podem não ocorrer como formas de palavras, é fácil perceber que a 'derivação regressiva' é um equívoco. Falamos da designação e do processo pressuposto por esta designação. 
Se compararmos este mecanismo com processos aditivos, constatamos quão pouco atenta é a perspetiva que continua a utilizar essa designação, ainda presente em alguns trabalhos universitários.

Um deverbal sufixado como moagem é construído a partir da base verbal na forma do radical. Repare-se que, nestes casos, a gramática tradicional não toma o infinitivo verbal como base à qual tem primeiro que se retirar o infinitivo e a VT, para depois se juntar o sufixo derivacional à forma restante dessa operação subtrativa. Para a gramática tradicional, em moagem, a base é o radical ao qual se anexa o sufixo-agem.

Por que razão, então, tomar o infinitivo como forma de base nos casos em que não ocorre afixação? Se para moagem, arborização, envelhecimento estão disponíveis três formas diferentes da base (radical, tema do presente, tema do particípio, respetivamente), por que não se observa da mesma maneira a formação de $a b r a c ̧ o$, voo, desmaio, etc.?

A designação de 'derivação regressiva' apoia-se numa visão concatenativa e superficial da morfologia.

Observemos estes produtos adequadamente: abraço/abraçar, voo/voar, desmaio/ desmaiar apenas partilham o radical, pelo que a base de derivação é o radical. É desta mesma maneira que consideramos que em moagem o sufixo é -agem e a base é o radical de moer (mo-).

A base de abraço é, então, abraç-. Porque este radical ocorre em sintaxe como verbo, é necessário que seja recategorizado como nome, para que se lhe possam juntar os morfemas flexionais de nome, bem como um índice temático que permita a sua integração na sintaxe.

Reequacionado o mecanismo de formação destes nomes, surge uma primeira questão: por que não considerar que o IT é o responsável pela recategorização de verbo em nome?

Todos os argumentos que utilizamos para mostrar que a VT do verbo não é responsável pela categoria verbal do mesmo verbo 
servem para explicar que o índice temático do nome não é responsável pelo facto de este ser um nome:

(1) o IT ocorre em nomes derivados e não derivados (casa, rato, vinho, pente);

(2) o IT pode ocorrer em nomes derivados por sufixação, em que, portanto, o sufixo é o responsável pela categoria de nome (deslumbramento, tristeza, desmaquilhante);

(3) nos advérbios ocorre IT - e e não é por esse facto que o lexema se volve em nome (agradavelmente);

(4) os mesmos ITs ocorrem em adjetivos.

Se retiramos a um morfema a capacidade derivacional, como explicamos a derivação entre base e produto? A derivação dá-se através da conversão, ou seja da mutação, laborada mental e paradigmaticamente, sem auxílio de operador derivacional, entre base e produto. O mesmo mecanismo que está na origem de verbos denominais, como açucarar, está na origem de nomes deverbais como abraço.

Desta estipulação advém outra questão: se se trata de conversão, ou seja de uma recategorização em que não intervêm operadores afixais, por que não se considera que essa conversão se dá na sintaxe e não no léxico? É que, aparentemente, a mudança de nome/verbo parece depender da cotextualização em que o radical se insere. Assim, se colocarmos um determinante à esquerda do radical, temos um nome (o abraço); se colocarmos o radical a concordar com um sujeito, temos um verbo (O João abraça a Maria todos os dias).

Esta perspetiva não é sustentável, pois não basta a simples integração de uma forma em determinado cotexto para aquela se comportar ou como um verbo, ou como um nome. Exemplos como *janelou, "salou, *cadeirou assinalam isso. Os semantismos de *salar/*janelar/"cadeirar não estão determinados no léxico. *Salou 
fica sem interpretação, enquanto *janelou e *cadeirou oscilam entre a interpretação de 'estar em cadeira/janela' e 'fazer cadeira/janela'. Já exemplos como açucarar, ancorar não sofrem do mesmo problema.

Uma das caraterísticas da formação no léxico é a idiossincrasia que semanticamente os produtos adquirem. Assim, o significado de qualquer produto possui caráter particular, na medida em que não se limita a uma paráfrase do significado da sua base. Por exemplo, martelar não significa 'pôr martelo em' e açucarar não significa 'utilizar açúcar para'. Um indivíduo que ponha uma pasta de açúcar no cabelo para fixar um penteado, não está a açucarar o cabelo. Um indivíduo que pouse um martelo para prender um papel que voa com o vento, não está a martelar; mas um indivíduo que prenda a âncora para fixar o navio, está a ancorar.

Nos produtos deverbais nominais, ocorrem semantismos muito variados (cf. secção 2.4.1. do cap. 2) que não são previsíveis à partida. Passeio, por exemplo, designa o evento de passear, mas também o local onde se passeia. Grito designa o evento, mas não o local. Sega designa evento, mas lixa designa evento e instrumento. Como seria possível formatar na sintaxe todos este semantismos que muitas vezes variam dentro do mesmo tipo semântico da base? Estas variação e riqueza semânticas só são possíveis no léxico, ou seja, num domínio mental em que se arquiteturam esquemas que permitem esta variabilidade.

Para além disso, se esta recategorização ocorresse na sintaxe, seria possível um nome converso de qualquer verbo, pois a sintaxe não está sujeita às exceções a que está a morfologia. Como veremos na secção 2.4.3., este tipo de formação de nomes apresenta muitas restrições de seleção das bases verbais. Significa isto que nem todos os verbos podem dar origem a um nome converso.

Há, no entanto, um tipo de nominalização que ocorre na sintaxe. Trata-se da simples nominalização em que ocorre determinação de um sintagma. Exemplo: Não me agrada o 'vou não vou' da Rita. o 'quero ir ao museu' da Ana fez-me levantar do sofá. O estudares 
profundamente a matéria traz-te muita segurança. São facilmente identificáveis estas nominalizações que tomam apenas um verbo no infinitivo ( $O$ estudar traz-te segurança). Estas nominalizações podem ocorrer sem restrições. Observe-se que são nominalizações em que não há imprevisibilidade na significação. A única diferença reside na construção sintática conseguida pela determinação. Nestes casos, qualquer verbo pode sofrer nominalização (Rodrigues 2013).

Outra questão levantada pela conversão é a seguinte: se não existem operadores formais responsáveis pela formação do produto, se não está presente no produto um morfema que indique que ele é derivado, como distinguir se, num par N/V, é o verbo ou o nome o derivado? Vejam-se os seguintes pares muro/murar, mura/murar. A observação da estrutura fonológica e morfológica não deixa perceber em que situações é que o nome é derivado ou derivante.

Os critérios que permitem essa identificação (Rodrigues 2001; Rodrigues 2009) são:

1) o nome é derivado e o verbo derivante se estiverem presentes os prefixos a-, en-, es- . Dado que são prefixos que operam apenas na formação de verbos, deduz-se que não podemos estar perante ruga $_{\mathrm{N}}>$ enruga $_{\mathrm{N}}>$ enrugar $_{\mathrm{V}}$, mas sim perante ruga $_{\mathrm{N}}>$ enrugar $_{\mathrm{V}}>$ enruga $_{\mathrm{N}}$

2) se o nome tiver apenas semantismos de caráter concreto, o nome é derivante e o verbo derivado (muro 'estrutura que separa um terreno' > murar 'prover de muro'). Se, para além de semantismos concretos, o nome apresentar significação abstrata de evento, o nome é derivado (murar 'caçar ratos, o gato' > mura $_{\mathrm{N}}$ 'evento de o gato caçar ratos'; colher 'apanhar'> colh $a_{\mathrm{N}}$ 'evento de apanhar').

3) se o nome tiver acentuação esdrúxula, ou seja, não coincidente com a acentuação geral dos nomes do português, o nome é derivante (âncora > ancorar, acúmulo > acumular). 
4) se o nome tiver estrutura argumental, o nome é derivado ( $a$ colha do morango pelos trabalhadores vs. *o muro de pedra pelo João).

5) se o verbo for de tema em -e ou $-i$, o verbo é derivante, porque a formação de novos verbos faz-se com a VT $-a^{11}$. Mas se o verbo for de tema em - $a$, não se determina a direcionalidade da derivação através deste critério.

\subsubsection{Morfologia não concatenativa: cruzamento vocabular, truncação, reduplicação, siglação/acronímia}

Existem mecanismos de formação de unidades lexicais, nos quais não intervêm constituintes morfológicos, em que operam mecanismos de natureza fonológica/prosódica ou gráfica. Estes processos são os seguintes:

Cruzamento vocabular (blending) (diciopédia; portunbol, burrocracia, pilantropia): resulta da junção de duas bases lexicais que podem ser encurtadas ou sobrepostas (Plag 2003: 121-126; Aronoff \& Fudeman 2005: 113-114; Cannon 2000; Fradin 2015).

Existem dois padrões de cruzamento vocabular, que decorrem da (dis)semelhança fónica entre as bases. Quando não se verifica semelhança fónica entre as bases, há encurtamento, resultando a forma nova da junção do material segmental pretónico da primeira base e da sílaba tónica e sequência postónica da segunda (dicio[nário] [enciclo]pédia). Nos casos em que há semelhança fónica entre as bases, as formas sobrepõem-se, geralmente incorporando-se a forma mais curta na base mais longa, resultando numa sequência com diferença fónica mínima relativamente a esta (pilantr[a] [f]ilantropia).

11 À exceção dos verbos formados com os sufixos -ec-e -esc-, que escolhem a VT $-e$. Estes, no entanto, não funcionam como bases destes nomes. 
Truncação (Plag 2003: 116-121; Aronoff \& Fudeman 2005: 115; Steinhauer 2015): a nova unidade resulta do encurtamento de segmentos fonológicos da unidade primeira, mantendo-se o semantismo, bem como a categoria lexical do lexema de origem (prof, cusco, proleta). A nova unidade apresenta diferenças de uso relativamente à unidade original: aquela que resulta de encurtamento é mais própria de um uso informal. Contudo, há casos em a unidade encurtada substituiu a palavra original como forma de uso mais frequente, levando a que a maioria dos falantes não tenha consciência de que se trata de formas truncadas (poucos falantes saberão que pneu é um encurtamento de pneumático e que cinema é um encurtamento de cinematógrafo). Nestes casos, o efeito discursivo de 'informalidade' não está presente nas formas encurtadas.

No padrão mais frequente de truncação, o apagamento segmental dá-se no limite direito da palavra-base, mantendo-se uma estrutura bissilábica (neura) ou trissilábica (anarca).

Nem todas as formas truncadas resultam da aplicação de princípios fonológicos. Em certos casos (foto, mini, otorrino), a unidade reduzida corresponde a um constituinte morfológico da palavra original, obrigatoriamente complexa.

A truncação é um dos processos mais frequentes de formação de hipocorísticos. Nestes casos, os padrões de redução são mais variados, podendo as formas ser monossilábicas (Quim) ou bissilábicas (Nando) e o apagamento de segmentos da base ser à esquerda (Quim, Nando) ou à direita (Isa, Bia).

Reduplicação: a unidade lexical resulta da repetição de uma unidade lexical ou de parte de uma unidade lexical previamente existente (Rio-Torto 1998c; Wiltshire \& Marantz 2000; Schwaiger 2015). Não é um processo de utilização muito frequente em português, se excetuarmos a hipocorização (Zezé, Nonô, Sissi, titi, vovô). No léxico não marcado ocorrem formas de reduplicação total (cai-cai, chupa-chupa, bombom, lufa-lufa). 
Existem, sobretudo na linguagem infantil, unidades formadas por redobro de sequências segmentais que não podem enquadrar-se neste processo, uma vez que não resultam da repetição de (parte de) uma unidade léxica (cocó, babá, totó, xexé), podendo ter um efeito onomatopaico (memé, popó, reco-reco).

Siglação/acronímia: processo que forma unidades através da extração do primeiro segmento de cada uma das palavras que constituem a expressão simplificada (Steinhauer 2015).

A manipulação das unidades gráficas/fonológicas da sequência original, no entanto, pode variar, em função da intenção de criar uma sequência grafo-fónica particular, sendo frequente a seleção de vários segmentos das bases.

A distinção entre sigla e acrónimo assenta essencialmente na forma como são pronunciadas as unidades reduzidas, que decorre dos mecanismos usados para a sua criação (quantos e quais os segmentos extraídos das formas de base). A sigla (GNR 'Guarda Nacional Republicana') tem uma pronúncia alfabética: é uma sequência dos nomes da letras; o acrónimo (IVA, EPAL) tem pronúncia silábica (as sequências de grafemas são pronunciadas como uma palavra do léxico comum).

As siglas/acrónimos substituem a sequência sintagmática de origem, não conhecendo os falantes, muitas vezes, essa estrutura. Algumas formas acronímicas estão lexicalizadas (sida 'Síndrome de ImunoDeficiência Adquirida'; óvni 'Objeto Voador Não Identificado'), nomeadamente alguns empréstimos, como Nato (North Atlantic Treaty Organisation), radar (RAdio Detecting and Ranging), laser (Light Amplification by Stimulated Emission of Radiation).

Estas formas funcionam como uma unidade lexical em português, com uma estrutura fonológica, uma categoria lexical e uma estrutura semântica. No entanto, admitem mais irregularidades fonológicas do que o léxico não marcado (estruturas silábicas irregulares, não redução de vogais átonas). O cap. 9 trata com detalhe este tipo de formações. 


\subsection{História da língua}

Embora este livro seja dedicado à descrição da formação de palavras do português contemporâneo, é necessário fazermos algumas considerações acerca da mudança que a estrutura da língua foi sofrendo historicamente. Além das mudanças que se verificam entre o latim e o português, há alterações internas a esta língua românica que são responsáveis pela existência de lexemas e formas de palavras que hoje parecem afastadas de regularidades.

Como já foi afirmado, a língua portuguesa tem numerosos constituintes eruditos e/ou sensíveis a este traço, sejam afixos ou radicais lexicais, cuja opacidade (argênteo, dióspiro, odontólogo, plumitivo, pirotécnico, quiromante) dificulta a interpretação por parte dos falantes não formalmente instruídos nessa matéria. Estes exemplos mostram que a formação de palavras pode recorrer a constituintes introduzidos de modo explícito e consciente por falantes que seguem o propósito de nomeação de novos referentes ou de referentes já existentes através de expressões propositadamente cultas (recorde-se o episódio anotado por Bluteau relativamente à palavra pirilampo, aqui enunciado em 1., nota 1). Nestes lexemas, o falante instruído nessas matérias possuirá paradigmas mentais em que se estruturam, por exemplo, formas como pirotécnico, pirilampo, pirobalística, piroclástico, piróforo, pela partilha do componente pir- 'fogo'. Atente-se, no entanto, que este componente não está disponível para a criação produtiva de formas como *pirificar, *pirão, *pirinho. Pelo contrário, a partir de elementos como flor são facilmente construídos produtos como florificar, florão. Note-se que -ific- (cf. cap. 4: 4.3.3.3.4) escolhe muitas vezes alomorfes eruditos (petrificar). Contudo, estes necessitam de estar implantados de modo ativo na mente do falante para poderem ser usados na formação de novas palavras.

O problema dos constituintes de argênteo, dióspiro, odontólogo, plumitivo, pirotécnico, quiromante está no facto de não estarem 
ativamente inscritos na mente do falante e não propriamente no facto de serem eruditos. Aliás, é comum encontrarem-se explicações erróneas sobre os constituintes de dióspiro como sendo dios + pyros 'fogo' 'fogo de deus', quando, na realidade, o segundo elemento é puron 'fruto, alimento', ou seja 'alimento de deus', o que revela a não interpretabilidade destes constituintes.

O mesmo ocorre com constituintes situados no pólo oposto destes eruditos: formatos arcaicos e rústicos como auga por água, giolho por joelho não se encontram disponíveis para gerar ativamente lexemas (e.g. "giolhada, *giolheira), não obstante haver ainda hoje falantes que produzem auga em vez de água e giolho por joelho. Isto não impede, no entanto, que um falante entendido nestas matérias produza, com uma intenção discursiva específica, giolhada, giolheira. É certo que estas formas têm menos probabilidade de se instalarem na língua do que as formas consideradas eruditas. Mas isso decorre de fatores sociolinguísticos e não de fatores estruturais.

Em todo o caso, a interpretabilidade destas formas está dependente de um conhecimento explícito, de caráter histórico, não acessível ao falante comum. Não é esta a situação dos mecanismos genolexicais ativos numa dada sincronia. Neste caso, o falante tem acesso implícito e inconsciente aos materiais de que se serve para formar palavras, sendo que estas podem, inclusivamente, ser coincidentes com palavras correspondentes na língua-mãe. Lexemas como declaração e pescador são apontados nos dicionários como possuindo uma etimologia latina. De facto, encontram-se atestadas as formas latinas DECLARATIONEM e PISCATOREM. Contudo, os constituintes de declaração (o tema do verbo declarar + sufixo -ção) e os de pescador (tema do verbo pescar + sufixo -dor) estão disponíveis na mente do falante, que deles possui um conhecimento analítico implícito para, através dos mecanismos genolexicais ativos na sincronia atual, ou seja, na gramática mental dos falantes, proceder à formação online destes e de outros lexemas. Assim, neste livro, 
e em consonância com o exposto, palavras deste tipo, passíveis de serem interpretadas como construídas em português, não serão consideradas apenas como importações do latim.

É importante que se tenha em atenção que na evolução de uma língua não são apenas as palavras como elementos isolados que se alteram. A visão de que a evolução da língua é a perda de umas palavras e o surgimento de outras é extremamente redutora. Para a formação de palavras, apenas nos importam as variações lexicais e morfológicas e não, por exemplo, as sintáticas. Contudo, mesmo a nível do léxico e da morfologia, deve ter-se em conta que as alterações se fazem por estruturas e não por unidades isoladas. Nas secções seguintes daremos conta de alguns desses fenómenos. Não pretendemos fazer uma listagem exaustiva de todos os fenómenos diacrónicos que afetam os paradigmas morfológicos e lexicais do português, mas apenas dar alguns exemplos.

\subsubsection{Perda de paradigmas}

No léxico atual do português existem lexemas que mostram uma regularidade não produtiva ou pouco produtiva. Esses lexemas integram constituintes morfológicos que o falante identifica como tal. Contudo, na formação de novos lexemas, esses constituintes não são utilizados (Haspelmath 2002: 51-52; Rainer 2015). É este o caso do feminino em -triz, em geratriz, imperatriz, face ao masculino -dor (gerador, imperador). Atualmente, o feminino faz-se através do segmento - a que se anexa a -dor. É possível encontrar duplos como geratriz/ geradora; embaixatriz/embaixadora. A distinção entre os seus significados é convencional. Embaixatriz designa 'mulher do embaixador'; embaixadora 'a que tem o cargo político'.

Outro exemplo de paradigma perdido é o dos particípios em $-u d$ - dos verbos de tema em - $e$. No português medieval, os par- 
ticípios de conhecer, saber, perder eram conheçudo, sabudo e perdudo, respetivamente (cf. Maia ([1986] 1997: 749-752). Hoje, essa forma resta apenas em expressões cristalizadas como teúda e manteúda, conteúdo.

No que diz respeito à morfologia derivacional, a perda do paradigma é gradativa. No âmbito dos nomes em -or, queimor atesta que é possível encontrar derivados com este sufixo, mas a sua produtividade é escassa (cf. cap. 1: 1.5.1. e 1.5.2.).

\subsubsection{Coalescência. Reanálise}

A coalescência é um processo em que se dá a união de dois constituintes morfológicos num só. Ou seja, o falante perde a noção de que se trata de dois constituintes e passa a vê-los como um único constituinte (Haspelmath 2002: 53-54). Em português, a coalescência está na origem das formas do condicional (contaria) e do futuro imperfeito do indicativo (contarei). Historicamente, estas formas correspondiam ao infinitivo do verbo principal, mais o verbo auxiliar haver conjugado nas formas contraídas (Contar hei, Contar hás, Contar hia, Contar hias...). A inclusão do verbo haver no morfema modo-aspeto-temporal dá origem a um morfema modo-aspeto-temporal uno (-re/-rá; -ria) ${ }^{12}$.

Um processo de coalescência em curso é acompanhado de reanálise da preposição de, por parte de muitos falantes que produzem hadem e hades em vez de hão de e hás de, respetivamente. A preposição é sentida como pertencendo ao radical verbal e por isso os morfemas de número-pessoa são colocados na fronteira direita daquele.

A criação de um sufixo a partir da junção de dois existentes anteriormente (Haspelmath 2002: 56) é exemplificada por -nci-.

12 Em relação às formas contraídas, veja-se Nunes ([1919] 1989: 298). 
Em latim o sufixo - $n t$ - formava o particípio presente: INDULGĒNTE-, particípio presente de INDULGĔO. O sufixo -IA anexava-se ao particípio presente e formava nomes de qualidade: INDULGENTǏA. Historicamente, os dois sufixos sofreram um processo de reanálise: deixam de ser dois constituintes e passam a ser um constituinte: -nci-. Repare-se que o processo é acompanhado por mudanças de caráter fonético-fonológico. $\mathrm{O}$ segmento /t/, seguido de segmento vocálico palatal /i/, deixa de ser oclusivo e passa progressivamente a sibilante $/ \mathrm{s} /{ }^{13}$.

Em português, o constituinte -nci- funciona como um sufixo uno. Se tomarmos o tema verbal radia-, anexamos-lhe -nci-, e assim obtemos radiância. Não existe o processo do latim segundo o qual temos o radical de radiante, ao qual se junta -ia. Se assim fosse, a forma obtida seria radiântia.

\subsection{Hierarquia entre constituintes}

Um lexema pode ser constituído por vários morfemas. No entanto, esses morfemas podem não estar diretamente envolvidos na formação desse lexema (Spencer 1991: 397-420). Vejamos os seguintes exemplos:

(45)incandescer, receber, conceção

Nos exemplos 45 encontramos as seguintes constituições em morfemas (excluem-se os morfemas flexionais): in+cand+esc; re+ceb; con+cep+ção.

Ainda que consigamos segmentar estes constituintes, vemos que a sua junção não é passível de se dar em português. Não reconhece-

13 Trata-se de um processo longo que passa por várias fases. Cf. Maia ([1986] 1997: 438-468 e 620-623), Silva (1991: 85-86 e 91-96) e Teyssier (1993: 9-11 e 49-52). 
mos os constituintes cand-, -ceb-e -cep- (cf. cap. 1: 1.3.) Mesmo que relacionemos cand- com cand- em candeeiro, candeia, candelabro, não interpretamos como autónomo o semantismo desse constituinte.

O mesmo ocorre para - ceb-e -cep- que, como já vimos, são recorrentes em conceber, conceção, deceção (mas não *deceber, embora exista em inglês deceive), perceção, perceber. Não obstante, o falante comum não atribui um semantismo autónomo a esse constituinte, ou seja, não apreende qual o contributo semântico que esse constituinte dá para o todo do lexema.

Estes exemplos mostram que pode haver uma constituição morfemática, sem que seja obrigatoriamente morfológica. Quer isto dizer que um lexema pode ser complexo, mas os seus constituintes não são semanticamente transparentes. Os constituintes morfemáticos não contribuíram para a construção do lexema na língua de chegada ou no estado atual dessa língua. Situação diversa ocorre com os exemplos (46):

(46) embarrilagem, ressoador, aprofundamento.

Nestes, os constituintes são: en+barril+agem; re+soa+dor; $a+$ profunda+ment $(o)$

Esta constituição em morfemas não equivale à hierarquia pela qual os morfemas foram anexados entre si. Para se formar embarrilagem não se procedeu à junção de en-e -agem ao radical barril. Para se formar ressoador, não se juntaram re- e -dor ao tema soa-. Para aprofundamento não se juntaram $a$ - e ment- ao tema profun$d a$-. A junção dos morfemas segue uma hierarquia que obedece às relações estabelecidas entre tipos de bases e tipos de produtos nas RFPs de palavras. Essa hierarquia está formatada sob o ponto de vista formal, mas também semântico.

A própria significação dos produtos deixa perceber essa hierarquia. As relações semânticas a ter em consideração devem resultar de uma análise linguística e não de mera impressão do falante. 
Assim, para formarmos embarrilagem juntamos o sufixo -agem à base embarril-. A relação semântica entre a base e o produto mostra-se em 'ação de embarrilar'. O prefixo em- é anexado à base barril numa fase anterior, dando origem ao verbo embarrilar.

$\mathrm{Na}$ formação de ressoador, anexa-se o sufixo -dor à base ressoa-. O prefixo re-fora anexado anteriormente ao verbo soar.

Para a formação de aprofundamento, juntou-se o sufixo -mentà base aprofunda-. O prefixo $a$ - juntara-se antes à base adjetival profund-para formar o verbo aprofundar.

Temos, assim, os seguintes percursos e as seguintes relações derivacionais:

(47) a. em+barril > embarrilar 'pôr em barril'

b. embarril+agem > embarrilagem 'ação de embarrilar'

(48) a. re+soar > ressoar 'tornar a soar'

b. ressoa+dor $>$ ressoador 'aquilo que ressoa'

(49) a. a+profund > aprofundar 'tornar profundo'

b. aprofunda+ment $(o)>$ aprofundamento 'processo de aprofundar'

Esta hierarquia entre os constituintes de um lexema não contradiz o que antes foi afirmado sobre o dinamismo do léxico mental. Quando dizemos que para construirmos o lexema aprofundamento temos de ter primeiro a base verbal aprofundar, tal não implica que o verbo tenha que existir histórica e cronologicamente antes de aprofundamento. No entanto, tem que existir enquanto lexema potencial gerável através de um padrão ou esquema mental. Tal não anula também o que ficou dito a respeito da formação online dos lexemas. Podemos gerar aprofundar online no momento em que geramos também online aprofundamento. O tempo de realização destas construções é ínfimo. Mas o processo é organizado hierarquicamente. 